The Capital Buffer Calibration for Other Systemically Important Institutions Is the Country Heterogeneity in the EU caused by Regulatory Capture? 
The Working Paper series of the Oesterreichische Nationalbank is designed to disseminate and to provide a platform for discussion of either work of the staff of the OeNB economists or outside contributors on topics which are of special interest to the OeNB. To ensure the high quality of their content, the contributions are subjected to an international refereeing process. The opinions are strictly those of the authors and do in no way commit the OeNB.

The Working Papers are also available on our website (http://www.oenb.at) and they are indexed in RePEc (http://repec.org/).

Publisher and editor

Editorial Board

of the Working Papers

Coordinating editor

Design

DVR 0031577

ISSN 2310-5321 (Print)

ISSN 2310-533X (Online)

(C) Oesterreichische Nationalbank, 2020. All rights reserved.

Oesterreichische Nationalbank

Otto-Wagner-Platz 3, 1090 Vienna, Austria

PO Box 61, 1011 Vienna, Austria

www.oenb.at

oenb.info@oenb.at

Phone (+43-1) 40420-6666

Fax (+43-1) 40420-046698

Doris Ritzberger-Grünwald, Ernest Gnan, Martin Summer

Martin Summer

Communications and Publications Division 


\title{
The Capital Buffer Calibration for Other Systemically Important Institutions - Is the Country Heterogeneity in the EU caused by Regulatory Capture?
}

November 20, 2020

Michael Sigmund ${ }^{1}$

\begin{abstract}
Since the 2007-2008 financial crisis, identifying systemically important financial institutions is a key topic in financial regulation. The European Banking Authority (EBA) has devised a buffer guideline for identifying other systemically important institutions (OSIIs) to address this issue. This guideline defines how to identify OSIIs by a scoring process, but crucially does not go as far as specifying an assignment process of scores into additional capital buffers. In this study, we empirically show that the OSII buffer assignment is very heterogeneous in Europe. Based on all European union banks that are classified as OSIIs between 2015 and 2018, we show that the OSII score has less impact on the OSII buffer than the headquarter country dummy of the bank while controlling for other important bank specific variables. We also quantify the extent of country heterogeneity in the buffer assignment, which accounts to around 90 bn EUR in additional capital requirements. Finally, we discuss if our results raise the suspicion of regulatory capture.
\end{abstract}

FEL codes: E58, C70, C58

Keywords: systemic risk; financial stability; macroprudential policy; other systemically important institutions; regulatory capture

Email address: michael.sigmund@oenb . at (Michael Sigmund)

${ }^{1}$ Oesterreichische Nationalbank (OeNB), Otto-Wagner-Platz 3, A-1090 Vienna, Austria. The views expressed in this paper are those of the authors and do not necessarily reflect those of the Eurosystem or the OeNB. This research did not receive any specific grant from funding agencies in the public, commercial, or not-for-profit sectors. 


\section{Non-technical summary}

Since the 2007-2008 financial crisis, identifying systemically important financial institutions is a key topic in financial regulation. the European Banking Authority (EBA) has devised a buffer guideline for identifying other systemically important institutions (OSIIs) to address this issue. This is guideline defines how to identify OSIls by a scoring process, but crucially does not go as far as specifying an assignment process of scores into buffers. The OSII score of a bank in a country is a weighted sum of size, importance, complexity and interconnectedness and is defined between 1 and 10,000. The weighting makes sure that OSII scores can be compared across countries and measures the relative share of a bank in a specific country with respect to the mentioned criteria. If a specific bank has more than 350 basis points, authorities have to declare this institution as an OSII. The authorities are allowed to decrease or increase this threshold to 275 or 425 basis points in order to account for country specific characteristics of the banking sector. Our sample includes around 212 OSIls and data between 2015 and 2018.

In addition to the assignment of OSIIs, the macroprudential regulators of each country should, with accordance to the EBA score, establish an appropriate OSII buffer. For institutions with a higher systemic importance, higher buffer rates should be calibrated. This additional buffer can be established by the regulators up to $2 \%$ of the total risk exposure amount consisting of Common Equity Tier 1 capital. Most regulators choose OSII buffers in discrete steps of 0.25 pp resulting in 9 possible OSII buffers.

Empirically, we try to find the best determinants for the OSII buffer assignment process. We account for these discrete OSII buffer steps by applying an ordered logit model. We also estimate a count data and an OLS model for robustness checks. All estimation results show that the OSII buffer assignment process is very heterogeneous across European union member states. We show that the OSII score has less impact on the OSII buffer than the headquarter country dummy of the bank while controlling for other important bank specific variables. We also quantify the extent of country heterogeneity in the buffer assignment, which accounts to around 90 bn EUR in additional capital requirements.

Our analysis reveals that each country in the European union judges the risks to financial stability stemming from the failure of an OSII quite differently. One could speculate on other motives, such as regulatory capture, which would cause a national regulator to assign a lower buffer than prudent countries would have assigned. A possible motive for a low OSII buffer could be that a bank should not breach the minimum regulatory capital requirements.

Based on our results, we suggest that countries should follow the recommendation by the European Systemic Risk Board that the national central bank should have a leading role in macro-prudential oversight. Central banks as the leading macroprudential authority assign a $0.5 p p$ higher OSII buffer on average than other macroprudential authorities. Our results have already initialized (emergency) activities by the European Central bank and by the ESRB. A working group has started to work on unifying the OSII buffer assignment process to reduce the amount of country. After all, the credibility of macroprudential regulation is at stake and currently regulatory arbitrage by moving the headquarter of large banking groups is possible. 


\section{Introduction: Systemic risk and financial regulation}

The 2007-2008 financial crisis has shown that identifying systemically important financial institutions is a key topic in financial regulation. The depth and severity of the financial crisis were clearly amplified by the assumption that certain financial institutions were too big to fail. At least many market participants made sometimes incorrect assumptions about an institution being too big to fail. The Lehman Brothers serve as such an example, as it was not saved, the shock waves through the financial system were measurable through stock market and CDS data from other financial institutions (Dumontaux and Pop, 2013) and from non-financial corporates (Chakrabarty and Zhang, 2012). On the interbank market, Ivashina and Scharfstein (2010) show that there was a run by short-term bank creditors, making it difficult for banks to roll over their short term debt in the U.S.

These papers provide empirical evidence that idiosyncratic shocks can easily spread through the entire financial system. In the context of interconnected financial institutions Iori et al. (2006) refer to this risk as "systemic risk". Most prominently, the Lehman Brothers was very interconnected to other financial institutions. To make matters worse, markets and policy makers most probably did not correctly anticipate the systemic risk or its consequences arising from the Lehman Brothers' default.

Especially since the 2007-2008 financial crisis, most policy makers and regulators agree that systemic risk poses a significant risk to financial stability. In ECB (2009), financial stability is defined as " $a$ condition in which the financial system - comprising of financial intermediaries, markets and market infrastructures - is capable of withstanding shocks and the unraveling of financial imbalances, thereby mitigating the likelihood of disruptions in the financial intermediation process which are severe enough to significantly impair the allocation of savings to profitable investment opportunities."

Without going into too many details, there are two relatively new approaches to quantify systemic risk. First, the academic approach to quantifying systemic risk is shaped by the contribution of Acharya et al. (2017), which is developed into SRisk (Brownlees and Engle, 2016; Engle et al., 2014), and of Adrian and Brunnermeier (2016), who introduce the $\triangle \mathrm{CoVaR}$ concept. In a nutshell, SRisk quantifies the capital shortfall of a bank given a strong market decline and $\Delta \mathrm{CoVaR}$ estimates the value-at-risk of the system as a whole when a particular bank faces distress, i.e. experiences a tail event.

Second, in the regulatory approach, simpler concepts are applied to identify globally systemically important institutions (GSIIs) and other systemically important institutions (OSIIs): ${ }^{2}$. Under current Basel III rules, the buffer for OSIIs, as well as their current implementations (FED, 2015; EBA, 2014) aims to address the risk stemming from the failure of an institution. In EBA (2014) a scoreboard approach is defined where a number of indicators weighted by the size of the banking system are added to an overall score. A higher score should reflect a greater risk to the financial system if the institution fails.

The reasons for these two different approaches for quantifying systemic risk are quite simple: The

\footnotetext{
${ }^{2}$ GSIIs are large institutions with an overall exposure measure of more than EUR 200 billion at the end of each year. Every GSII is therefore also classified as an OSII. See BIS $(2012,2013)$ for more details.
} 
applications of SRisk and $\triangle \mathrm{CoVaR}$ require the bank to be publicly listed. However, according to Siebenbrunner et al. (2017), this is only true for $22 \%$ of banks in the US, $4 \%$ in the UK, $3 \%$ in France and as little as $1 \%$ in Germany. From a regulatory point of view, SRisk and $\triangle \mathrm{CoVaR}$ are therefore unfortunately not applicable to identify all OSIIs in the European union. On the other hand, the OSII score, as the second best solution, can be calculated for every bank and if the OSII score is above a certain threshold, then this bank is classified as an OSII (see Section Appendix E for more details). However, most critically, there is no guideline in EBA (2014) how to translate the score into a buffer.

Given the absence of an OSII buffer assignment guidance, national regulators have two options. First, according to Schuknecht and Siegerink (2020), based on the "international cooperation perspective", some regulators might choose a more rigorous assignment of OSII buffers. Second, under the "special interest perspective", national regulators might push back against a stricter OSII buffer assignment process. Under the first hypothesis, Schuknecht and Siegerink (2020) argue that a high share of foreign ownership and signalling effects might lead to a stricter assignment process. Under the second hypothesis, Schuknecht and Siegerink (2020) argue that banks would want weak implementation of regulation when they are weak, and only strengthened when they are sure to meet the standards and are in good overall shape. Igan et al. (2019) argue that special interests undermined support for tight rules and enforcement before the global financial crisis. The "special interest perspective" is closely related to regulatory capture (Stigler, 1971; Laffont and Tirole, 1991). Regulatory capture occurs when a special interest is prioritized over the general interests of the public. The benefits of higher OSII buffers for the public (tax payers) are straightforward. In line with the literature (Wheelock and Wilson, 2000; Rime, 2001), EBA (2014) claims that the OSII buffer should reduce an institution's probability of default and therefore reduces the expected losses (probability of default times losses given default) caused by this institution's failure in the financial system. ${ }^{3}$ Thus, if an institution is classified as an OSII, an additional insurance in the form of a higher regulatory capital ratio could be required. The OSII buffer is therefore an indirect solution to the too big too fail dilemma. In theory, if an additional buffer was not enough to save a failing OSII, there would be further new regulatory options such as the single resolution mechanism (Kern, 2015; Howarth and Quaglia, 2014), which is the central institution for bank resolution in the euro area, and should ensure an orderly resolution of failing banks with minimum costs for taxpayers and to the real economy. ${ }^{4}$

The benefits of lower OSII buffers for banks are also straightforward. Ceteris paribus, a higher capital ratio reduces the return on equity. Some OSIIs might be forced to raise new capital, while for all others at least their management buffer ${ }^{5}$ shrinks.

Our main contribution to the literature is the following: To the best of our knowledge, we are the first to empirically show that the OSII buffer assignment is very heterogeneous in Europe, although there is a unified guideline (EBA, 2014) how to identify and score OSIIs. In the process, we empirically test

\footnotetext{
${ }^{3}$ The theory about expected losses is called "expected impact" theory in the context of OSIIs (FED, 2015; BIS, 2013).

${ }^{4}$ Howarth and Quaglia (2014) describe the historical development of the single resolution mechanism within in the euro area.

${ }^{5}$ According to the ECB Guide to the internal capital adequacy assessment process, management buffer refers to capital exceeding the regulatory and supervisory minima.
} 
the assumption that the OSII score has an influence on the OSII buffer for all European OSIIs. Second, we debate the "international cooperation perspective hypothesis" vs. the "special interest perspective hypothesis" in the view of potential regulatory capture. Third, we test the robustness of our results by different estimation methods and sub samples of our data. Fourth, we formalize the qualitative approach to regulatory capture by a Nash bargaining problem.

Our results show that there is a large amount of country heterogeneity in the OSII buffer assignment that cannot be attributed to the OSII score. We can explain some of these differences by adding selected control variables that in our opinion proxy regulatory capture to some extend.

The remainder of the paper is structured as follows: Section 2 gives a formal definition of the EBA scoring process (EBA, 2014). Section 3 describes the data set. In Section 4, we describe the empirical models to analyze the OSII buffer assignment process. In Section 5, we describe our results starting with the ordered logit model to highlight the country heterogeneity in the OSII buffer assignment. Next, we quantify the heterogeneity in a capital requirement scheme simulation with a count data model. Finally, we make a cross country comparison based on an ordinary least squares model. Section 6 concludes and provides some policy recommendations. ${ }^{6}$

\section{The EBA OSII Scoring Process}

In Article 131(3) of Directive 2013/36/EU (CRD) the following guideline defines the scoring process for assessing the systemic importance of institutions.

\footnotetext{
${ }^{6}$ In Section Appendix E, we discuss a potential economic theory for the OSII buffer assignment problem as a Nash bargaining solution between the regulator and the banks' representatives. This economic theory is very much in line with Calomiris and Haber (2015) who argue that banking regulation is a complex bargain between banking industry and regulators. Bad outcomes for the public have resulted in chronic weaknesses in financial systems. We also discuss the estimated parameters of the Nash bargaining solution.
} 
Table 1: Scoring Process

\begin{tabular}{|l|l|l|}
\hline Criterion & Indicators & Weight \\
\hline \hline Size & Total assets & $25 \%$ \\
\hline Importance & Value of domestic payment transaction & $8.33 \%$ \\
& Private sector deposits from depositors in the EU & $8.33 \%$ \\
& Private sector loans to recipients in the EU & $8.33 \%$ \\
\hline Complexity/Cross-border activity & Value of OTC derivatives (notional) & $8.33 \%$ \\
& Cross-jurisdictional liabilities & $8.33 \%$ \\
& Cross-juridictional claims & $8.33 \%$ \\
\hline Interconnectedness & Intra financial system liabilities & $8.33 \%$ \\
& Intra financial system assets & $8.33 \%$ \\
& Debt securities outstanding & $8.33 \%$ \\
\hline
\end{tabular}

Source: EBA (2014).

The weighted numbers of the scoring process in Table 1 are then used to calculate the OSII score of bank $i$ as follows:

$$
\text { OSII-Score }_{i}=10,000 * \sum_{\text {Ind } \in \in \text { OSII-Indicators }} w^{\text {Ind. }} \frac{\text { Ind }_{\cdot i}}{\sum_{j=1}^{N} \text { Ind }_{\cdot j}} .
$$

Where $N$ is the number of banks in a specific country and Size, Importance, Complexity and Interconnectedness are the weighted criteria of Table 1 . By dividing each weighted criteria by the weighted sum (across all banks in a country) of each criteria, it is possible to compare OSII scores across countries. In this step, the EBA scoring process adjusts for different sizes of the banking sector across countries. Multiplying the result by 10,000 makes sure that each bank has a score in the open interval $(0,10,000] .^{7}$ In our empirical analysis, we transform the OSII score to lie between 0 and 100 to measure it on the same scale as the other variables. Therefore, the OSII score is a weighted "market share" of bank $i$ in country $j$.

This score is re-calculated annually by the designated authorities and must be published. The scores are used in a two step procedure to determine which banks are classified as an OSII:

(1) If a specific bank has more than 350 basis points, authorities have to declare this institution as an OSII. The authorities are allowed to decrease or increase this threshold to 275 or 425 basis points in order to account for country specific characteristics of the banking sector. ${ }^{8}$

\footnotetext{
${ }^{7}$ Hypothetically, a score of 10,000 would imply that there was only one bank in a specific country. A score of close to 0 would imply that a bank has a balance sheet sum close to 0 .

${ }^{8}$ In our dataset, regulators classified 38 banks as OSIIs with an OSII score below 275 basis points. We re-estimate all our models also without including these 38 observations and our results do not change. These tables are available from the
} 
(2) If there are further relevant institutions, authorities can designate them as OSIIs. However, institutions with a score of smaller or equal to 4.5 basis points shall not be designated as OSIIs.

In addition to the assignment of OSIIs, the authorities of each country should, with accordance to the EBA score, establish an appropriate OSII buffer. For institutions with a higher systemic importance, higher buffer rates should be calibrated. This additional buffer can be established by the authorities up to $2 \%$ of the total risk exposure amount consisting of Common Equity Tier 1 capital. Due to this additional capital, the stability of individual OSII should be strengthened and should prevent a "dominoeffect" in national banking systems in a bust phase. A common scheme for defining an O-SII buffer with an underlying score does not exist. Country's authorities have the possibility to set their buffer rate according to their own methods.

Some facts about the scoring process in combination with the Systemic Risk Buffer (SyRB) have to be mentioned. There are three important exception defined in Article 131 of Directive 2013/36/EU (CRD) we take into account in our study:

(1) §8 if an OSII is a subsidiary of either a GSII or an OSII with a parent institution in an other European country the OSII buffer shall not exceed the buffer on the consolidated level.

(2) In $§ 14$ of this article it is stated that if an institution, "on an individual or sub-consolidated basis is subjected to an OSII buffer and a systemic risk buffer (...) the higher of the two shall apply".

(3) In $\S 15$, if the SyRB is applied on all exposures in the member state but is not applied on exposures outside the member state, the OSII buffer and the SyRB shall be cumulative.

The $\S 8$ of this directive is not a statistical problem, since it seldom happens. We decide to use the OSII buffer assigned in the notification to the ESRB, even if this OSII buffer was not binding (such as in the case of Unicredit Bank Austria with a 2\% OSII buffer assignment but only 1\% would be binding). 77 of the OSIIs in our dataset are owned by parent OSII from another European country. To account for this fact, we include a "subsidiary" dummy and re-estimate our main results to see if $\S 8$ is of any empirical importance. ${ }^{9}$

$\S 14$ and $\S 15$ could potentially be relevant. The limit of the SyRB buffer is $3 \%$ and the limit of the OSII buffer is $2 \%$. If a country takes the higher of the two, it could happen that there is only a SyRB, but not an OSII buffer, although most countries follow best practise and assign an OSII buffers. Only two countries in our sample (CZ and DK) do not set an OSII buffer at all. However, removing these two countries from our data does not change our results significantly (see Appendix C).

Although most countries do not apply $§ 15$, we control for this possibility by adding country dummies to most models. There is also a new paragraph in the CRD V (Art 131 §5 and Art 131 §5a) which needs to be implemented by member states by the end of 2019 and will allow designated authorities to set OSII Buffer rates of up to $3 \%$ (with approval of the European Commission even higher). Moreover, the

authors upon request or can be easily estimated given the online supplementary files.

${ }^{9}$ Since including the "subsidiary" dummy does not change our main results, we only present the results in Appendix D in Table D.12. 
OSII buffer and Systemic risk buffer will be cumulative as the restriction in Art 133 para 4 CRD IV that only the higher of the two shall apply will be waived. ${ }^{10}$

These new regulatory developments might completely change the dynamics of the SyRB and the OSII assignment processes and increase the importance of understanding the interrelation between these two buffers. Potential consequences of this new regulation are discussed in Section 5.3.

\section{Data}

Our dataset consists of three different sources. First, the OSII score and buffer data are gathered from the European systemic risk board (ESRB). Second, we add bank-specific variables from SNL Financial Institutions and Bank data. Third, we add worldwide governance indicators from Kaufmann et al. (2011). The summary statistics of all used data can be found in Table A.9.

\subsection{OSII-Data: Score and Buffer}

All data on OSII buffers and OSII scores are based on the publications of the European union member state authorities to the ESRB. ${ }^{11}$ The regulatory framework for these publications was set by the European Banking Authority (EBA, 2014) and is defined in the Article 131(3) of Directive 2013/36/EU (CRD). ${ }^{12}$ According to this document, the European union member state authorities should calculate an OSII buffer rate for each bank according to the EBA scoreboard approach (see Table 1).

In our analysis, we include banks from European union member states and Iceland that report the OSII buffers to the ESRB database. This leads to a total number of 473 observations which include 212 different OSIIs from 28 countries between 2015 and 2018. In our analysis, we use the target OSII buffers of each bank. In many cases, regulators allow a phase-in until the target OSII buffers are legally binding. Hence, we do not analyze the step-wise increased OSII buffers until the OSII buffers are reached. For the estimations, we use all available observations but we do not include bank fixed effects because we only have 2.23 observations on average per OSII.

In Figure 1, we make the first important observation: The difference in the distributions of the OSII buffers and the OSII scores already indicates that the OSII scores might not be solely responsible for the resulting OSII buffers. The OSII buffer histogram should be similar to the OSII score histogram, if the OSII score is the most important determinant of the OSII buffer.

\footnotetext{
${ }^{10}$ See https://eur-lex.europa.eu/legal-content/EN/TXT/HTML/?uri=CELEX: 32019L0878\&from=EN\#d1e3913-253-1 for more details.

${ }^{11}$ All OSII buffers for European union member state banks are available on https : //www. esrb. europa . eu/ national_policy/systemically/html/index.en.html.

${ }^{12} \mathrm{CRD}$ refers to the Capital Requirements Directives, a supervisory framework in the European Union which defines the Basel II and Basel III rules on capital measurement and capital standards. The new CRD IV package (commonly known as Basel III) was published on the $17^{\text {th }}$ of July 2013, came into force in January 2014 and includes the EU Directive 2013/36/EU and the EU Regulation 575/2013.
} 
Figure 1: OSII Buffers vs. OSII Score Frequency
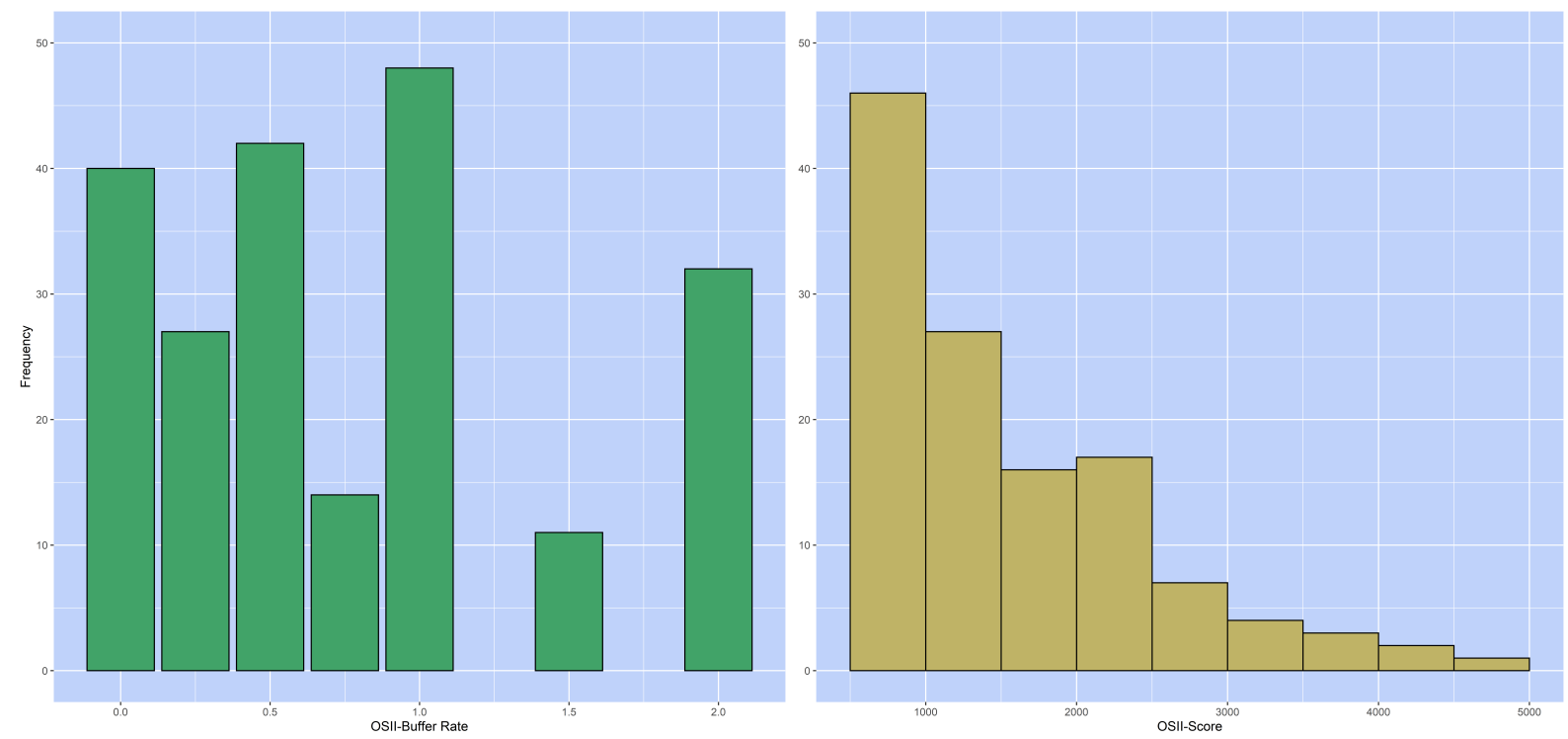

Source: ESRB database from 2015 to 2018.

https://www.esrb.europa.eu/national_policy/systemically/html/index.en.html

The left histogram shows the frequency of OSII buffers between $0 \%$ and $2 \%$. The right histogram shows the frequency of OSII scores between 0 and 5000 .

All banks are included only the first time, when they are classified as OSIIs with their respective OSII buffer. Thus, no OSII is included twice.

In Table 2, we provide an overview on the first OSII buffer decisions in each country. We report the number of OSIIs, the number of different OSII buffers, the different OSII buffers, the maximum OSII buffer, the minimum and maximum OSII score. 
Table 2: Overview on first OSII Buffer decisions

\begin{tabular}{|l|l|l|l|l|l|l|l|}
\hline Country & First Decision & Nof Banks & Nof buckets & Buckets & Max. OSII buffer & Min Score & Max Score \\
\hline AT & 2016 & 6 & 2 & $1 ; 2$ & 2.00 & 282.00 & 2056.00 \\
BE & 2015 & 8 & 2 & $0.75 ; 1.5$ & 1.50 & 270.00 & 2600.00 \\
BG & 2015 & 10 & 3 & $0.5 ; 0.75 ; 1$ & 1.00 & 344.00 & 1977.00 \\
CY & 2017 & 6 & 4 & $0.5 ; 1 ; 1.5 ; 2$ & 2.00 & 721.00 & 2823.00 \\
CZ & 2017 & 7 & 1 & 0 & 0.00 & 405.00 & 2103.00 \\
DE & 2016 & 15 & 4 & $0.5 ; 1 ; 1.5 ; 2$ & 2.00 & 110.67 & 2853.42 \\
DK & 2016 & 6 & 1 & 0 & 0.00 & 147.00 & 4969.00 \\
EE & 2016 & 2 & 1 & 2 & 2.00 & 1906.00 & 3040.00 \\
ES & 2016 & 6 & 3 & $0.25 ; 0.75 ; 1$ & 1.00 & 402.00 & 3887.00 \\
FI & 2017 & 3 & 2 & $0.5 ; 2$ & 2.00 & 589.00 & 2396.00 \\
FR & 2016 & 6 & 4 & $0.25 ; 0.5 ; 1 ; 1.5$ & 1.50 & 201.00 & 2474.00 \\
GR & 2015 & 4 & 1 & 1 & 1.00 & 2064.00 & 3416.00 \\
HR & 2016 & 9 & 2 & $0.25 ; 2$ & 2.00 & 255.00 & 2630.00 \\
HU & 2017 & 8 & 3 & $0.5 ; 1 ; 2$ & 2.00 & 402.00 & 2682.00 \\
IE & 2016 & 7 & 4 & $0 ; 0.25 ; 0.5 ; 1.5$ & 1.50 & 385.00 & 2213.00 \\
IS & 2017 & 3 & 1 & 2 & 2.00 & 2682.00 & 3071.00 \\
IT & 2016 & 3 & 3 & $0.25 ; 0.75 ; 1$ & 1.00 & 512.00 & 3844.00 \\
LT & 2017 & 4 & 2 & $0.5 ; 2$ & 2.00 & 638.00 & 4283.00 \\
LU & 2017 & 4 & 1 & 0.5 & 0.50 & 291.00 & 313.00 \\
MT & 2015 & 3 & 3 & $0.5 ; 1.5 ; 2$ & 2.00 & 448.00 & 2411.00 \\
NL & 2016 & 5 & 2 & $1 ; 2$ & 2.00 & 202.00 & 3825.00 \\
PL & 2017 & 12 & 4 & $0 ; 0.25 ; 0.5 ; 0.75$ & 0.75 & 144.00 & 1367.00 \\
PT & 2017 & 6 & 4 & $0.25 ; 0.5 ; 0.75 ; 1$ & 1.00 & 524.50 & 2449.50 \\
RO & 2016 & 10 & 1 & 1 & 1.00 & 282.00 & 1775.00 \\
SE & 2015 & 4 & 1 & 2 & 2.00 & 1247.00 & 4311.00 \\
SI & 2017 & 7 & 2 & $0.25 ; 1$ & 1.00 & 535.00 & 3071.00 \\
SK & 2017 & 5 & 2 & $0.5 ; 1$ & 1.00 & 568.00 & 2155.00 \\
UK & 2016 & 15 & 2 & $0 ; 1$ & 1.00 & 57.00 & 1577.00 \\
\hline
\end{tabular}

This table reports the first OSII buffer decisions for each country.

"First Decision" reports the year of the first OSII buffer decisions. "Nof Banks" refers to number of banks. "Buckets" reports which OSII buffers are assigned.

Max. (Min.) OSII buffer reports the maximum (minimum) OSII buffer for each country.

Min. (Max.) OSII score refers to the minimum (maximum) OSII score in each country. The OSII score is defined between 0 and 10,000 .

In Table 2, we observe that no country selected more than four "OSII Buffer Buckets" to classify their OSIIs. Hence, the very granular OSII score does not lead to many different OSII buffer assignments even if in a country a wide range of OSII scores is observed. A very good example is SE, here an OSII with a score of 1,247 receives the same OSII buffer as an OSII with a score of 4, 311 .

\subsection{Detecting and Measuring Regulatory Capture}

Detecting and measuring regulatory capture is extremely difficult. Following Carpenter (2014), most of the time, regulatory captures are studied qualitatively on a case-by-case basis. Carpenter (2014) suggest to check five points for a potential case of regulatory capture.

1. Does there exist an identifiable "general interest" $(\mathrm{W})$ or goal for which the regulation was created?

2. Does there exist an identifiable interest or goal of the "industry" (I) in which the regulation shall be applied? 
3. W and I conflict in the sense that in applications of regulation or enforcement, the public interest or statutory obligations of the agency and the producer/special interest do not coincide.

4. Does there exist some mechanism of undue or disproportionate influence (capture) whereby the industry attempts to induce the regulator to choose I over W?

5. A weak probabilistic condition is that the regulator's choice of I comes with higher probability with capture than without.

A more formal modelling of regulatory capture is presented in Appendix E.

We argue that there is a "general interest" in solving (reducing) the too-big-to-fail dilemma, as the public represented by the the tax payer has no interest in bailing out failing OSIIs. Although there is no commonly accepted agreement on the maximum size of the OSII buffer, Passmore and von Hafften (2019) show that the current maximum OSII buffers (also the buffers for globally important banks) would have been too small based on the experience of the 2007/08 financial crisis for the US banks. They suggest to raise capital requirements 5.50 to 8.25 percentage points for banks currently subject to surcharges. Most likely, the "industry" does not like any regulation that reduces their return on equity.

Next, we believe that there exist some mechanism of undue or disproportionate influence (capture) whereby the industry attempts to induce the regulator to choose I over W. This mechanism is definitely complex has multiple stages and players. In the first stage of the OSII buffer regulation, regulators and industry might have to agree on an EU-wide "CRD directive" and then on the content (definition of OSII, buffer range, ect.). Next, each member state has to nationally implement the EU-CRD directive, which includes the reference to EBA (2014). There is even an important intermediary step, in which policy makers have to agree on the national macroprudential authority (see Appendix E for more details). In the next step, the macroprudential authority has to write a first draft on the OSII buffers and inform all OSIIs about their OSII buffer proposals. Next, the OSIIs have the opportunity to challenge these decisions and might send formal protest letter. In the final step, the designated authority is then responsible for issuing the OSII buffer decisions to the respective OSIIs.

Given the fact that OSII scores are comparable across countries, Figure 1 and Table 2 show evidence that the OSII buffer assignment process is very different across countries and that in countries with less "industry" influence the OSII buffers might be higher. We also follow Carpenter (2014) and suggest a few variables that could potentially (at least indirectly) influence the degree of regulatory capture.

First, we include the Tier 1 capital ratio and the operating income ratio (income divided by total assets) from SNL Financial Institutions and Bank data as possible predictors for the OSII buffer. These variables capture the strength of a bank. Weak banks might try harder to lobby for a lower OSII buffer assignment. They would prefer that regulators award buffers on the basis of banks' capabilities rather than banks' too-big-to-fail risk profile. Clearly, these bank-specific variables only indirectly measure regulatory capture.

Next, we look at very specific macroprudential regulations, namely the SyRB, and its national imple- 
mentation that have similar intentions to reduce the too-big-too-fail dilemma. The SyRB is intended to mitigate the vulnerability of institutions against risks emanating from the financial system as a whole or a part thereof by holding additional own funds in order to increase the loss-absorbing capacity of these institutions. There is no maximum limit for this buffer, but depending on its level and the impact on other Member States, authorization from the European Commission may be required. ${ }^{13}$

Interestingly, not all euro area member states have implemented the SyRB in their national regulations. Only AT, BG, HR, CZ, DK, EE, FI, HU, IS, NL, RO, SK and SE allow a SyRB buffer. There could be several reasons why countries have not implemented the SyRB in their national regulation. In some countries, policy makers might have agreed that the OSII buffer is sufficient. In others, policy makers could have anticipated that the OSII and the SyRB buffer will be cumulative in the future. In some countries, policy makers might wait until a unified framework for the SyRB exists similar to EBA (2014) for the OSII score. In any case, we believe that the implementation and the setting of the SyRB is a good indicator of regulatory capture. The benefits of no SyRB are straightforward for (large) banks. There is no danger of higher minimal capital requirements from this macroprudential buffer.

On the country level, we add control of corruption from the worldwide governance indicators database (Kaufmann et al., 2011). According to Kaufmann et al. (2011), control of corruption captures perceptions of the extent to which public power is exercised for private gain, including both petty and grand forms of corruption, as well as "capture" of the state by elites and private interests.

Finally, we add the dummy variable "Mapru by Central Bank" to measure regulatory capture. The simple idea is the central bank should be more independent from "industry" and other political influences than other institutions, since central banks in most developed countries are institutionally independent from political interference. The dummy variable "Mapru by Central Bank" has a value of 1, if the central bank has the leading role in the macroprudential regulation and, as a consequence, writes the first draft on the OSII buffer assignment. This group of countries includes BE, CY, CZ, EE, FI, FR, GR, HU, IE, LT, MT, NL, PT, RO, SE, SK and additionally AT, BG, DE, LV and SI.

\section{Empirical Approach}

In this section, we describe three different econometric models to explain the buffer for OSIIs. Although the buffers could lie anywhere in the interval $[0,2]$, they only take values between $0 \%$ and $2 \%$ in steps of $0.25 \%$. Thus, each regulator seems to choose from a set of nine possibilities which calls for an ordered response model. However, given the fact that the nine different buffer possibilities also have a cardinal interpretation (e.g. $1 \%$ is higher not only different from $0.5 \%$ ), we also apply the count data model with the Poisson distribution. On the down side, in standard count data models there is no upper limit of the dependent variable.

\footnotetext{
${ }^{13}$ See https://www.esrb.europa.eu/national_policy/systemic/html/index.en.html for more details.
} 
In summary, there is a trade-off between ordered response, count data models and ordinary least squares: The OSII buffer has an upper limit (2\% OSII buffer limit) and only nine buffer rates are chosen, which calls for an ordered response model. However, the cardinal interpretation of the OSII buffer calls for a count data model. Finally, the ordinary least squares estimator makes fewer distributional assumptions than the ordered probit model and the count data model (no equidispersion) but still has a cardinal interpretation. The ordinary least squares estimator is also more robust than the maximum likelihood estimators of the ordered probit and the count data models.

In the following table, we summarize the advantages and disadvantages of each estimator.

Table 3: Empirical models

\begin{tabular}{|l|l|l|l|l|l|}
\hline Estimation method & $0 \%$ lower Bound & $2 \%$ upper bound & Discrete steps & Cardinal interpretation & Robustness \\
\hline Ordered probit & yes & yes & yes & no & no \\
Poisson count data & yes & no & yes & yes \\
Ordinary least squares & no & no & yes & yes \\
\hline
\end{tabular}

Table 3 shows that no estimator fits perfectly to describe the "data generating process" of the OSII buffer assignment. As a consequence, we estimate all three models. Fortunately, all three estimation methods lead to similar outputs, strengthening our main result, a high degree of country heterogeneity in the OSII buffer assignment.

\subsection{Ordered Response Model}

In order to estimate the order response model, we define a single latent variable $y_{i}^{*}$ (which we only observe when it crosses the thresholds, e.g. $0.25 \%$ or $0.5 \%$, ect.):

$$
\begin{aligned}
& y_{i}^{*}=x_{i}^{\prime} \beta+\epsilon_{i}, \\
& y_{i}=k \quad \text { if } \quad \alpha_{i-1}<y_{i}^{\star} \leq \alpha_{j} .
\end{aligned}
$$

We observe $y_{i}=k$ as long as $y_{i}^{\star}$ lies in the respective interval. The probability that observation $i$ will select alternatives $1, \ldots, k, \ldots, K$ is given by:

$$
\begin{aligned}
& P\left(y_{i}=0\right)=P\left(\alpha_{0}<y_{k}^{\star} \leq \alpha_{1}\right), \\
& P\left(y_{i}=1\right)=P\left(\alpha_{1}<y_{k}^{\star} \leq \alpha_{2}\right), \\
& \cdots \\
& P\left(y_{i}=k\right)=P\left(\alpha_{k-1}<y_{k}^{\star} \leq \alpha_{k}\right), \\
& \cdots \\
& P\left(y_{i}=K\right)=P\left(\alpha_{K}<y_{k}^{\star} \leq \alpha_{K+1}\right) .
\end{aligned}
$$

Inserting $y_{i}^{*}$ from Eq. (2) into Eq. (3), we end up with: 


$$
\begin{aligned}
P\left(y_{i}=k\right) & =P\left(\alpha_{k-1} \leq x_{i}^{\prime} \beta+\epsilon_{i} \leq \alpha_{k}\right), \\
& =P\left(\alpha_{k-1}-x_{i}^{\prime} \beta \leq \epsilon_{i} \leq \alpha_{k}-x_{i}^{\prime} \beta\right), \\
& =P\left(\epsilon_{i} \leq \alpha_{k}-x_{i}^{\prime} \beta\right)-P\left(\epsilon_{i} \leq \alpha_{k} x_{i}^{\prime} \beta\right), \\
& =F\left(\alpha_{k}-x_{i}^{\prime} \beta\right)-F\left(\alpha_{k-1}-x_{i}^{\prime} \beta\right) .
\end{aligned}
$$

For $F(\cdot)$ researches usually insert either the normal or the logistic distribution. In the first case, we would deal with the ordered probit model in the second case with the ordered logistic model. The important parameters $\beta$ and $\alpha_{1}, \ldots, \alpha_{K}$ can be incorporated in the following likelihood function:

$$
L(\beta, \alpha)=\prod_{i=1}^{N} \prod_{k=0}^{K} P\left(y_{i}=k\right)^{I\left(y_{i}=k\right)} .
$$

$I\left(y_{i}=k\right)$ is the indicator function being 1 if $y_{i}=k$. The log-likelihood function of Eq. (5) follows with:

$$
\mathcal{L}\left(\alpha_{k}, \beta\right)=\sum_{i=1}^{N} \sum_{k=1}^{K} \mathbf{I}_{\left\{y_{i}=k\right\}} \log \left(P\left(y_{i}=k\right)\right)
$$

Following the usual properties of maximum likelihood estimators, the parameters obtained from maximizing the log-likelihood are consistent and asymptotically normally distributed. The asymptotic variance of the estimated parameters can also be estimated straightforwardly (Wooldridge, 2002).

To measure the goodness of fit, we use the McFadden $R^{2}$ (McFadden et al., 1977) which is calculated as follow:

$$
R^{2}=1-\frac{\mathcal{L}_{\text {fit }}}{\mathcal{L}_{0}}
$$

$\mathcal{L}_{\text {fit }}$ refers to the log likelihood of the full model, whereas $\mathcal{L}_{0}$ refers to the log likelihood of the model without predictors.

We use the logistic distribution function instead of the normal distribution function (ordered probit model), since the logistic distribution function has heavier tails and therefore often increases the robustness of estimation results. For estimating the ordered logit model, we use the code of Venables and Ripley (2002). ${ }^{14}$

\footnotetext{
${ }^{14}$ We also apply the codes of Harrell (2018) and Carroll (2017) which lead to the same results.
} 


\subsection{Count Data Model}

In this section, we show how the OSII buffer assignment can be analyzed by a count data model. This model is based on the binary choice model. It therefore serves as a first robustness check for the ordered logit model. For the estimation of the count data model, we use the Poisson distribution. Following Cameron and Trivedi (2005) this distribution is described by:

$$
P\{Y=y \mid x\}=\frac{e^{(-\mu)} \mu^{y}}{y !}, y=0,1,2,3, \ldots
$$

In order to account for the Possion distribution, we transfer the OSII buffers into natural numbers (e.g. $0 \rightarrow 0,0.25 \rightarrow 1,0.5 \rightarrow 2$ and so on).

The Poisson estimation requires equidispersion which means that the mean and the variance is equal:

$$
E\left\{y_{i} \mid x_{i}\right\}=\mu_{i}=\operatorname{VAR}\left\{y_{i} \mid x_{i}\right\}=e^{\left(x_{i}^{\prime} \beta\right)}
$$

In order to test the validity of our results, we test for equidispersion in Section 5.2 and Appendix B.

The model is estimated via maximum likelihood after applying the log-transformation:

$$
\mathcal{L}(\beta)=\sum_{i=1}^{N}\left[y_{i} e^{\left(x_{i}^{\prime} \beta\right)}-e^{\left(x_{i}^{\prime} \beta\right)}-\log \left(y_{i} !\right)\right]
$$

The estimated parameters are based on the first order condition of Eq. (10), which has no closed form solution:

$$
\frac{\partial \mathcal{L}}{\partial \beta}=\sum_{i=1}^{N}\left(y_{i}-e^{\left(x_{i}^{\prime} \beta\right)}\right) x_{i}=0 .
$$

To find the optimal solution for $\beta$, we use the Newton-Raphson method (Süli and Mayers, 2003). To evaluate the goodness of fit of the Poisson estimation, we again use the McFadden $R^{2}$ which is described in Eq. (7). 


\section{Empirical results}

In this section, we present our empirical results. In Section 5.1, we present the estimation output of the ordered logit model. We also give an interpretation of the results in terms of conditional probabilities. We estimate how likely it is that a bank $i$ in country $j$ receives an OSII buffer of $1.5 \%, 1 \%, 0.5 \%$ or $0.25 \%$ if its OSII score is 1500 . In Section 5.2, we present a simulation exercise based on the count data model estimation (see Section 4.2) in which we calculate the OSII buffer of bank $i$ if the bank was in Germany (with the German country dummy coefficient). In Section 5.3, we provide further robustness checks by estimating the OSII buffer assignment process with ordinary least squares and make a cross country comparison of the OSII buffer assignment process. We take the largest bank in each European union member state and use the OLS estimation result and assign the OSII buffer hypothetically in each country.

For all estimation methods, we also look at the policy perspective of the OSII buffer assignment process in the context of the "international cooperation perspective", the "special interest perspective" and regulatory capture. We try to explain the country heterogeneity following the discussion in Schuknecht and Siegerink (2020); Igan et al. (2019); Calomiris and Haber (2015).

\subsection{Ordered Logit Model}

In this section, we present and discuss the estimation results of the ordered logit model. The dependent variable, as described in Section 4.1, is the OSII buffer for each OSII in each country set by the corresponding regulatory authorities. The independent variables are included in several steps. In the first step, we show the model only with OSII Score as an explanatory variable. In the second step, we add 27 country dummy variables and country AT as the intercept. In the third model, we add the SyRB, the Tier 1 ratio (-1), the operating income ratio (-1) and control of corruption (-1) as explained in Section 3.2. In the fourth model, we add the dummy variable "Mapru by Central Bank" instead of country dummies.

In Table 4, for each of the five models, we estimate six intercepts (also called cut points), which are specific to the $K$ events defined in Eq. (2) and separate the various levels of the response variable. As there are no observed OSII buffers at $1.25 \%$ and at $1.75 \%$, the corresponding intercept cannot be estimated.

In all models, the OSII score coefficient is positive and statistically significant. The size of the OSII score coefficient increases, if we control for country dummies and the other explanatory variables. A higher score increases the probability of an higher OSII buffer. This means that on average the regulatory authorities take the OSII scores into account when they set the OSII buffers. Thus, the hypothesis, that regulators take the OSII scores in the OSII buffer assignment into account, can be supported.

However, as shown in the second column of Table 4 the coefficients of the country dummies are completely different and reach from around -46 to around 1. It leads to an important question: How much does the country of an OSII matters for the OSII buffer? The size of the country dummies already indicate that it might be more important than the OSII score. 
Table 4: Ordered Logit Models

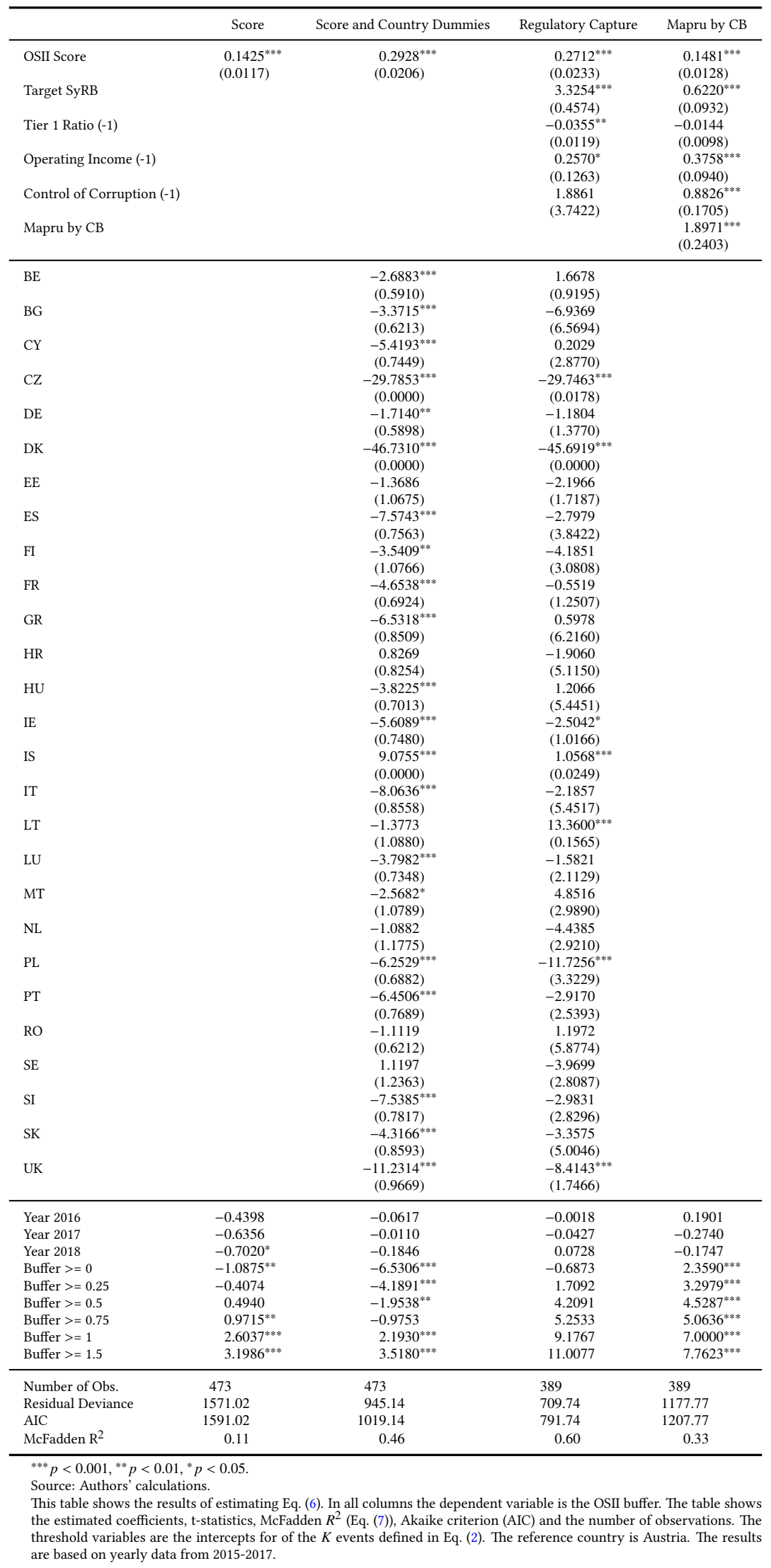


Figure 2: Estimated probability of certain OSII buffer conditional on an OSII Score of 1500.
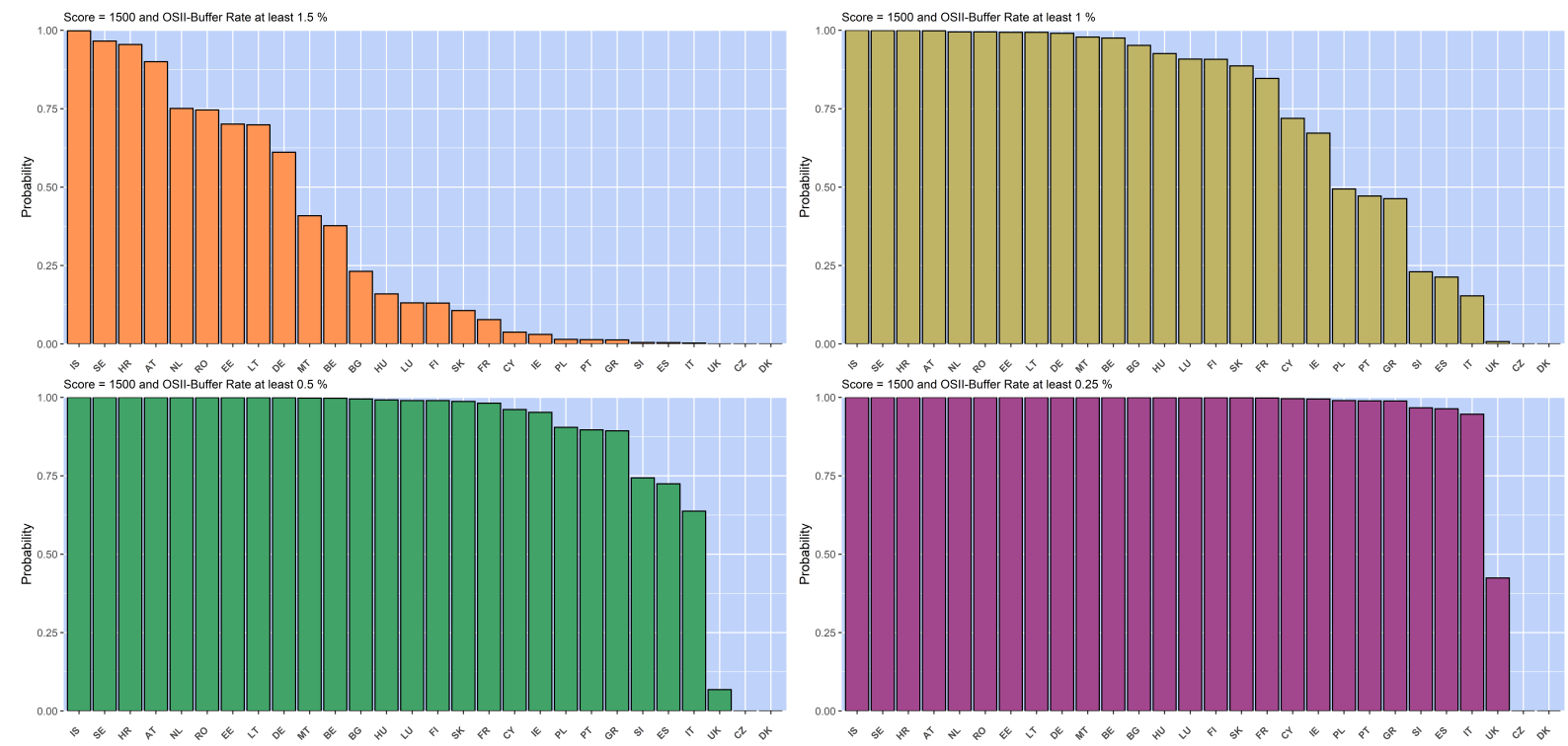

Source: Authors' calculations. The estimated probabilities are based on the results of Eq. (6) presented in Table 4 in column

"Score and Country Dummies". The graph shows the conditional probability that a bank with an OSII score of 1500 in a specific country receives an OSII buffer of at least $1.5 \%, 1 \%, 0.5 \%$ and $0.25 \%$.

As the coefficients of an ordered logit model do not allow to answer this question directly without translating these coefficients into probabilities, we calculate the probabilities of each country to set the OSII buffer rate on the different levels from $0.25 \%$ to $1.5 \%$ given that the institution has a score of 1500 . The results are shown in Figure 2.

The upper left graph in Figure 2 shows that only a few countries would assign an OSII buffer of at least $1.5 \%$ to a bank with an OSII score of 1500 . For many countries the results (based on the coefficients in Table 4) suggest that many countries would set a OSII buffer of at least $1.5 \%$ with very low to zero probability. Notable exceptions are AT, BE, DE, EE, HR, IS, LT, MT, NL, RO and SE.

The upper right graph in Figure 2 shows that already more countries would assign an OSII buffer of at least $1 \%$ to a bank with an OSII score of 1500 . However, countries like CZ, DK, ES, IT, SI and UK still assign a very low to zero probability. The lower left graph in Figure 2 presents similar probabilities as in the upper right graph. Finally, the lower right graph identifies those countries such as $\mathrm{CZ}$ and DK that do not assign OSII buffers at all as described in Section 3.

Overall, Figure 2 gives a very good impression, how differently regulatory authorities in the European union assign OSII buffers to their respective banks even if the OSII scores are similar. In line with industry intuition, how much buffer an institution is attributed, does not only depend on the institutions' OSII score, but also depends - and even more strongly - on the local regulator.

This outcome would support the "international cooperation perspective" for AT, BE, DE, EE, HR, IS, LT, MT, NL, RO and SE. Whereas CZ, DK, ES, IT, SI and UK seem to follow the "special interest perspective". 
After establishing a high degree of country heterogeneity in the OSII buffer assignment, we try to explain the country heterogeneity following the discussion in Section 3.2. We add the Tier 1 ratio and operating income divided by total assets (both lagged by one year) as an explanatory variables to account for the weak banks argument in support of the "special interest perspective". From these two variables, the operating income ratio (-1) has the expected positive and significant coefficient. A higher operating income enables banks to generate more Tier 1 capital without issuing new shares or similar instruments. The Tier 1 ratio has an economically small but negative sign. Maybe regulators believe that well capitalized banks do not need an additional OSII buffer or it is related to the phase-in process of the full OSII buffer.

Control of corruption (-1), which measures the possibility of "capture" by elites and private interests, has the expected positive coefficient. A higher control of corruption in a country leads ceteris paribus to a higher OSII buffer.

Probably the best variable to proxy regulatory capture in the context of the OSII buffer assignment is the SyRB. As expected, its coefficient is positive and significant. Regulators who apply positive SyRB also assign higher OSII buffers.

The coefficient of "Mapru by CB" also has a positive sign and is highly significant, supporting the hypothesis that central banks are more independent than other public institution as well as the recommendation by ESRB (2011a) that the national central bank should have a leading role in macro-prudential oversight.

Comparing column 2 to columns 3, we see that on average the absolute size and the significance of the country heterogeneity (expressed by the country dummies) are reduced. In particular, this observation is true for BE, BG, CY, CZ, DE, DK, ES, FI, FR, GR, HU, IT, LU, PT, SK and UK.

\subsection{Capital Requirement Simulation}

In this subsection, we make a cross-country comparison based on the following capital requirement simulation: We predict the OSII buffers for each bank of the sample based on the Poisson count data model (see Section 4.2). We repeat the model specifications the previous section. The estimation results are shown in Table B.10. ${ }^{15}$ Overall, the results in Table B.10 are very similar to Table 4, confirming the country heterogeneity in the OSII buffer assignment and the importance of our explanatory variables.

In our capital requirement scheme simulation, we choose Germany as the reference country model for two reasons. First, Germany is the largest economy in the euro area. Second, the German regulators neither set the highest nor the lowest OSII buffers. They apply an OSII buffer assignment model that is

\footnotetext{
${ }^{15}$ Our count data estimation results fit with equidispersion. It means that the mean and the variance are equal. The test statistic is calculated with the code of Kleiber and Zeileis (2008) and gives a value of -0.85 with a p-value of 0.8 which gives no indication of rejecting the null hypothesis of equidispersion. Therefore, we do not need to consider another distribution (e.g. negative binomial distribution).
} 
around the median model. All else equal and assuming that the new OSII buffers would be binding, the additional capital requirements of all banks in the sample would amount to around 90 billion euros. We also show the banks with the largest potential capital requirement and surplus based on this simulation.

To predict the OSII buffer of bank $i$ in country $j$, we multiply its score by 0.0376 (see Table B.10) and add the Germany country dummy $(1.3456-0.2508)$. Then, we assume that all banks have to increase or decrease their capital requirements by the calculated OSII buffer, even if a bank holds more capital than the "new" regulatory requirement. It could be that some banks have a CET1 ratio far beyond the requirements of Basel III, even with the additional OSII buffer requirements. However, as already mentioned, the draft by the European Parliament to add the OSII buffer and the SyRB was accepted, now the OSII buffer and the SyRB are added instead of applying only the higher of the two. ${ }^{16}$ As this change in legislation was accepted our capital requirement simulation will be even more relevant in $2020 / 21$, as for most of the 212 OSIIs the SyRB is as least as high as the OSII buffer.

Figure 3 shows the capital requirement for each country cumulated in absolute values. The simulation reflects the case where each European bank would copy the German OSII buffer setting by their authorities. In nine countries the capital requirements for the banks would be above one billion Euro. The banks of UK would be most affected. The UK, Czech and Danish banks would have to increase their CET 1 capital by approximately 20 billion Euro. The only two countries in which the banks have capital surplus larger than 1 billion Euro on CET 1 in comparison to Germany are Sweden and Austria. Based on this simulation, the regulatory capital minimum of European banks would increase by 82.3 billion Euro. In some major EU member state countries, if the German OSII translation process was applied, this would even leave some prominent banks undercapitalized. Consequently, one could ask if some regulators award buffers on the basis of banks' capabilities rather than banks' systemic risk profile.

To put 90 billion Euro in perspective to the most recent financial crisis, we refer to Eurostat (2015) and Eurostat (2018) from 2007 to 2017 which report the total costs for the general governments in the EU-28 to support financial institutions to 241.3 bn euro. ${ }^{17}$

\footnotetext{
${ }^{16}$ See http: //Www. europarl . europa.eu/sides/getDoc.do?pubRef $=-\% 2 \mathrm{f} \% 2 \mathrm{fEP} \% 2 \mathrm{f} \%$ 2fTEXT\%2bREPORT\%2bA8-2018-0243\%2b0\%2bDOC\%2bXML\%2bV0\%2f\%2fEN\&language=EN for more details.

${ }^{17}$ See https://ec.europa.eu/eurostat/web/government-finance-statistics/ excessive-deficit/supplemtary-tables-financial-crisis for further details and tables.
} 
Figure 3: Simulation: Additional capital requirements for banks with reference country Germany

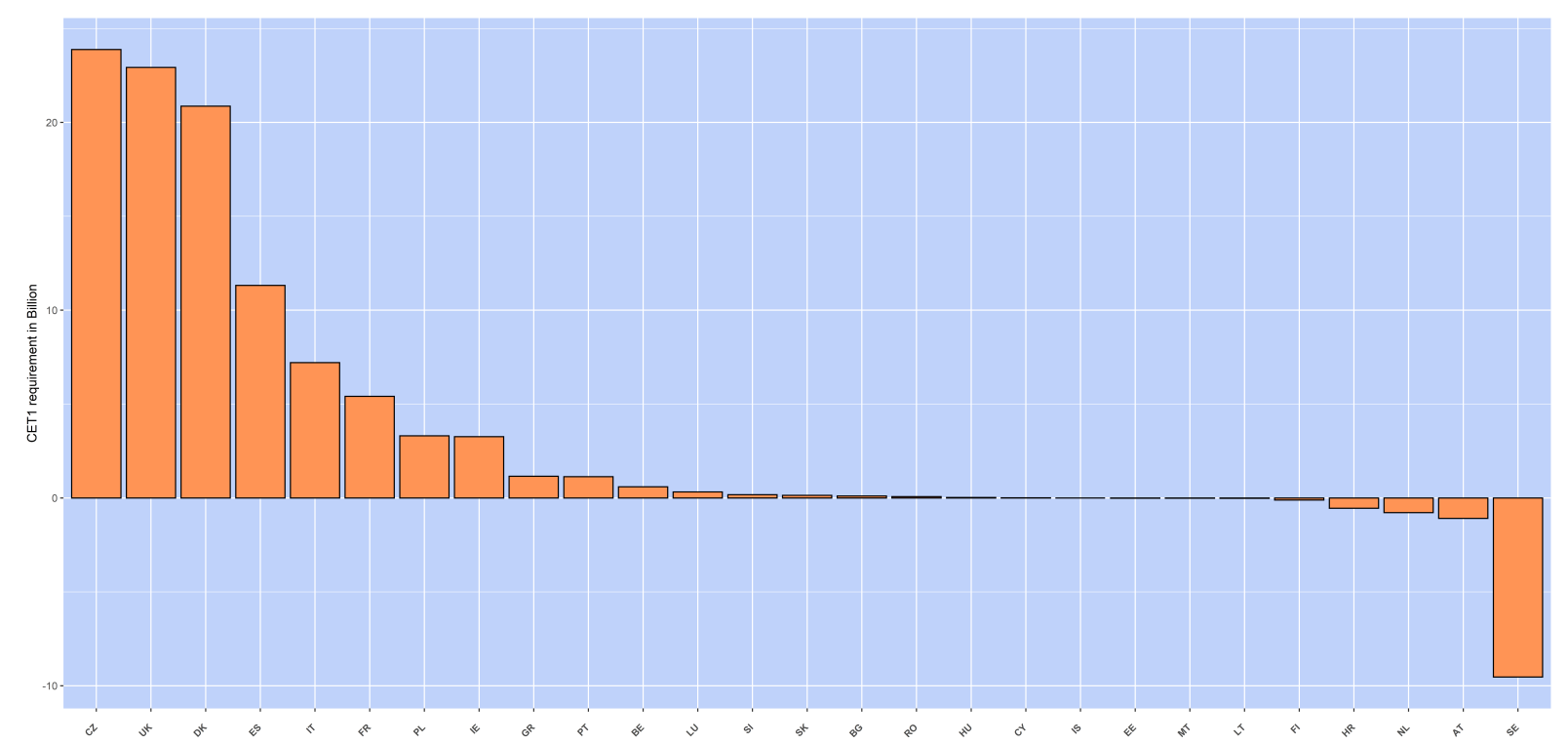

Source: Authors' calculations. The graph show the capital requirements and surpluses which are cumulated over all banks in a country in reference to the German OSII buffer estimations. The capital requirements are calculated via the Poisson estimation. It is the difference between the German OSII buffer model and the assigned OSII buffer.

In Table 5 we report the largest banks in absolute values with capital requirements and capital surplus. The largest capital requirements would be in UK, DK and CZ. However, due to their high CET1 ratios the Danish and Czech banks would not be really affected by an increase in the CET1 ratio. Based on our data 5 out of 10 banks in the Table 5 have a lower CET1 ratio than the European mean. Thus, in the case of an increase of the OSII buffer rates, these banks could be affected.

Table 5: Simulation of largest capital requirements and surplus by banks

\begin{tabular}{rlrr}
\hline Bank & Country & Capital requirement & CET1 ratio \\
\hline Dankse Bank & DK & 16.30 & $16.28 \%$ \\
HSBC & UK & 10.71 & $13.60 \%$ \\
Ceska sporitelna & CZ & 6.97 & $16.64 \%$ \\
CSOB & CZ & 6.03 & $17.18 \%$ \\
Santander & ES & 5.88 & $12.53 \%$ \\
Komercni banka & CZ & 5.31 & $18.02 \%$ \\
Unicredit S.p.A & IT & 3.87 & $8.15 \%$ \\
Barclays & UK & 3.66 & $12.36 \%$ \\
UniCredit CZ & CZ & 3.37 & $18.99 \%$ \\
BBVA & ES & 2.92 & $12.18 \%$ \\
\hline
\end{tabular}

\begin{tabular}{rlrr}
\hline Bank & Country & Capital surplus & CET1 ratio \\
\hline SEB & SE & -4.28 & $18.84 \%$ \\
Svenska AB & SE & -3.55 & $21.25 \%$ \\
Swedbank & SE & -2.92 & $24.14 \%$ \\
ABN Amro & NL & -0.78 & $17.06 \%$ \\
Erste Group & AT & -0.51 & $13.36 \%$ \\
RBI & AT & -0.45 & $13.88 \%$ \\
Raiffeisen Austria & HR & -0.23 & $16.93 \%$ \\
Santander UK Plc & UK & -0.22 & $11.64 \%$ \\
Splitska Banka & HR & -0.16 & $19.91 \%$ \\
ING Bank BE & BE & -0.14 & $14.52 \%$ \\
\hline
\end{tabular}

Source: Authors' calculations, SNL. The capital requirements (surpluses) are in billion euro. This table shows the 10 largest banks with CET1 requirements (left table) and the CET1 surplus (right table) according to a higher OSII buffer. The reference country is Germany and the values of the table are predicted via the Poisson count data estimation results (see Table B.10 column 2). The capital requirements (surpluses) are in billion euro are based on the first OSII buffer decisions for the respective OSIIs. The mean CET1 ratio of European banks was 13.78\% in 2016. 


\subsection{Robustness Check OLS}

In this section, we apply ordinary least squares to our OSII buffer models to see if our results are driven by the more complex assumptions and numerical optimization behind the order logit or the count data models. In Table 6 we present our results. Again, we estimate similar coefficients as in Table 4 and Table B.10. Thus, the large degree of country heterogeneity, the small but significantly positive coefficient of the OSII score, the importance of the SyRB, control of corruption (-1) and "Mapru by CB" are confirmed. 
Table 6: OLS Estimation: Nash Bargaining Solution

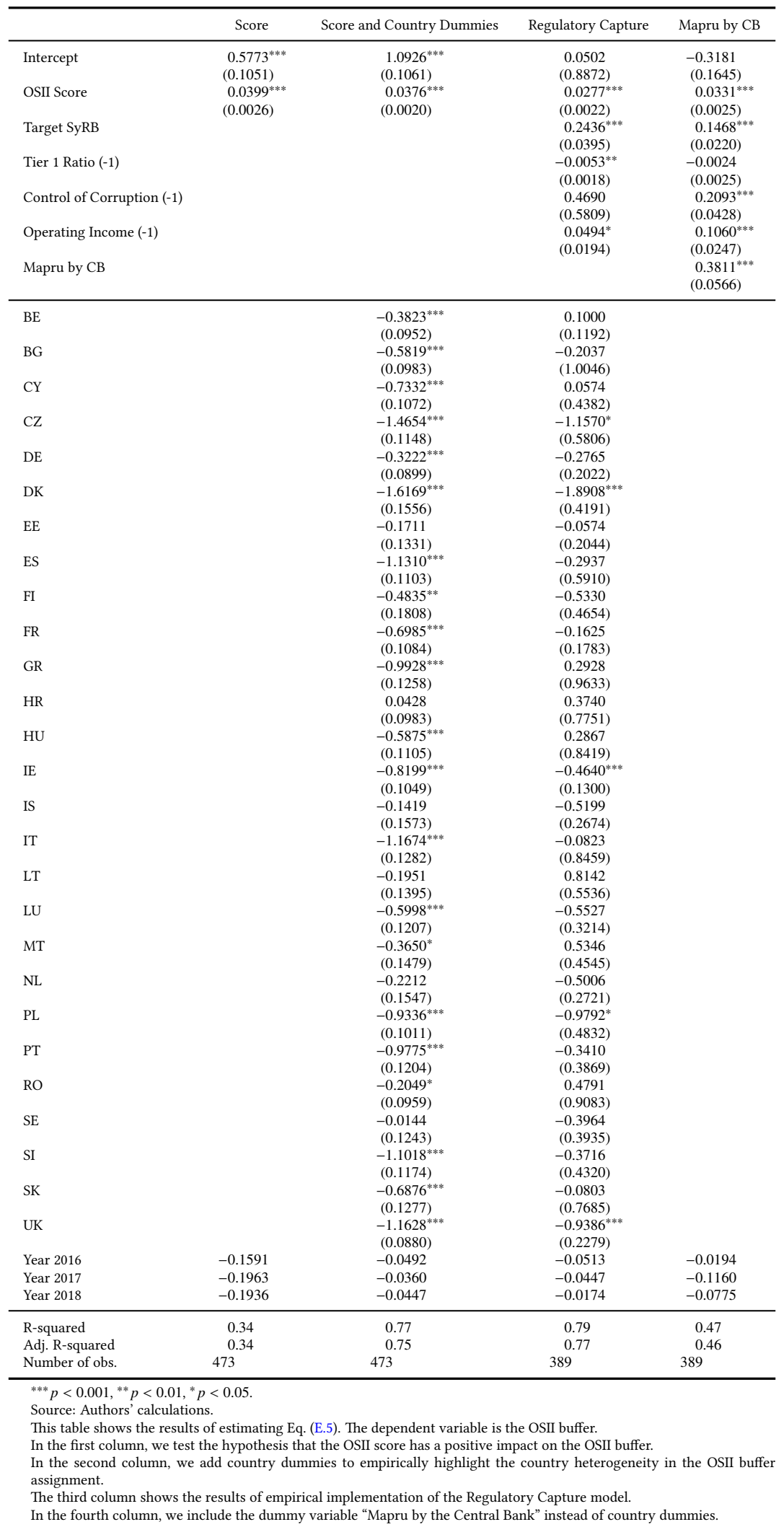


Next, we make a cross country comparison of the OSII buffer assignment process. We take the largest bank in each European union member state and use the OLS estimation result in the second column ("Score and Country Dummies model") of Table 6 to assign the OSII buffer hypothetically in each country. In particular, the off-diagonal values show what OSII buffer would be assigned to a bank, if it was under a different macroprudential regulation. For example, we predict the OSII score of Erste Group (largest bank in Austria) with the Austrian model (intercept and OSII score coefficient), with the Belgium model (intercept plus BE coefficient and OSII score coefficient) and so on. Thus, the off-diagonal elements of the resulting matrix show what OSII buffer would be assigned to a bank, if it was under a different macroprudential regulation. There are two main reasons for this cross country comparison. First, we use the OLS model to avoid any upper bound on the predicted OSII buffers. Second, as discussed in Section 3, under the new regulatory framework, which will be in place in 2020, the OSII buffer and the SyRB buffer are cumulative not "the higher of the two" is applied. Moreover, the new maximum OSII buffer is $3 \%$ instead of $2 \%$. Based on the existing country specific methodologies, which are likely to change under the new framework, the new upper limit of $3 \%$ is very relevant. For high OSII scores, countries would hypothetically assign OSII buffers above $2 \%$.

Table 7: OLS prediction of a bank's OSII buffer in different countries

\begin{tabular}{|c|c|c|c|c|c|c|c|c|c|c|c|c|c|c|}
\hline & AT & $\mathrm{BE}$ & BG & $\mathrm{CY}$ & $\mathrm{CZ}$ & $\mathrm{DE}$ & DK & $\mathrm{EE}$ & ES & FI & FR & GR & HR & $\mathrm{HU}$ \\
\hline Erste Group & 2.00 & 1.63 & 1.43 & 1.26 & 0.53 & 1.67 & 0.37 & 1.83 & 0.87 & 1.52 & 1.30 & 1.02 & 2.04 & 1.41 \\
\hline BNP BE & 2.03 & 1.66 & 1.46 & 1.30 & 0.56 & 1.70 & 0.40 & 1.86 & 0.90 & 1.55 & 1.33 & 1.05 & 2.07 & 1.44 \\
\hline UC Bulbank & 1.79 & 1.42 & 1.23 & 1.06 & 0.33 & 1.47 & 0.17 & 1.62 & 0.66 & 1.32 & 1.09 & 0.82 & 1.84 & 1.21 \\
\hline $\mathrm{BOC}$ & 2.24 & 1.87 & 1.68 & 1.51 & 0.78 & 1.92 & 0.62 & 2.07 & 1.11 & 1.76 & 1.54 & 1.26 & 2.28 & 1.66 \\
\hline CSOB CZ & 1.84 & 1.47 & 1.27 & 1.11 & 0.38 & 1.52 & 0.22 & 1.67 & 0.71 & 1.36 & 1.14 & 0.86 & 1.88 & 1.26 \\
\hline DB & 2.12 & 1.75 & 1.56 & 1.39 & 0.66 & 1.80 & 0.50 & 1.95 & 0.99 & 1.65 & 1.42 & 1.15 & 2.16 & 1.54 \\
\hline Dankse Bank & 2.92 & 2.55 & 2.35 & 2.19 & 1.46 & 2.60 & 1.29 & 2.75 & 1.79 & 2.44 & 2.22 & 1.94 & 2.96 & 2.33 \\
\hline Swedbank & 2.19 & 1.82 & 1.63 & 1.46 & 0.73 & 1.87 & 0.57 & 2.02 & 1.06 & 1.72 & 1.49 & 1.22 & 2.24 & 1.61 \\
\hline Santander & 2.70 & 2.33 & 2.13 & 1.97 & 1.24 & 2.38 & 1.08 & 2.53 & 1.57 & 2.22 & 2.00 & 1.72 & 2.74 & 2.11 \\
\hline OP Group & 1.95 & 1.58 & 1.38 & 1.22 & 0.49 & 1.63 & 0.33 & 1.78 & 0.82 & 1.47 & 1.25 & 0.97 & 1.99 & 1.37 \\
\hline BNP FR & 1.98 & 1.61 & 1.42 & 1.25 & 0.52 & 1.66 & 0.36 & 1.81 & 0.85 & 1.51 & 1.28 & 1.00 & 2.02 & 1.40 \\
\hline BOG & 2.33 & 1.96 & 1.77 & 1.60 & 0.87 & 2.01 & 0.71 & 2.16 & 1.20 & 1.86 & 1.64 & 1.36 & 2.38 & 1.75 \\
\hline Zagrebacka & 2.17 & 1.80 & 1.61 & 1.44 & 0.71 & 1.85 & 0.55 & 2.00 & 1.04 & 1.70 & 1.48 & 1.20 & 2.22 & 1.59 \\
\hline OTP HU & 2.21 & 1.84 & 1.65 & 1.48 & 0.75 & 1.89 & 0.59 & 2.04 & 1.08 & 1.74 & 1.51 & 1.24 & 2.26 & 1.63 \\
\hline BOI & 1.88 & 1.51 & 1.32 & 1.15 & 0.42 & 1.56 & 0.26 & 1.71 & 0.75 & 1.41 & 1.18 & 0.90 & 1.92 & 1.30 \\
\hline Landsbankinn IS & 2.25 & 1.88 & 1.68 & 1.52 & 0.79 & 1.93 & 0.63 & 2.08 & 1.12 & 1.77 & 1.55 & 1.27 & 2.29 & 1.66 \\
\hline Unicredit S.p.A & 2.49 & 2.12 & 1.93 & 1.76 & 1.03 & 2.17 & 0.87 & 2.32 & 1.36 & 2.02 & 1.80 & 1.52 & 2.54 & 1.91 \\
\hline AB SEB bank & 2.66 & 2.29 & 2.09 & 1.93 & 1.20 & 2.34 & 1.04 & 2.49 & 1.53 & 2.18 & 1.96 & 1.68 & 2.70 & 2.08 \\
\hline Societe Generale Bank LU & 1.60 & 1.23 & 1.04 & 0.87 & 0.14 & 1.28 & -0.02 & 1.43 & 0.47 & 1.13 & 0.90 & 0.63 & 1.65 & 1.02 \\
\hline $\mathrm{BOV}$ & 1.96 & 1.58 & 1.39 & 1.22 & 0.49 & 1.63 & 0.33 & 1.79 & 0.82 & 1.48 & 1.26 & 0.98 & 2.00 & 1.37 \\
\hline ING Bank NL & 2.49 & 2.12 & 1.92 & 1.76 & 1.02 & 2.16 & 0.86 & 2.32 & 1.36 & 2.01 & 1.79 & 1.51 & 2.53 & 1.90 \\
\hline PKO BP & 1.64 & 1.27 & 1.08 & 0.91 & 0.18 & 1.32 & 0.02 & 1.47 & 0.51 & 1.17 & 0.95 & 0.67 & 1.69 & 1.06 \\
\hline Caixa & 2.01 & 1.64 & 1.45 & 1.28 & 0.55 & 1.69 & 0.39 & 1.84 & 0.88 & 1.54 & 1.31 & 1.04 & 2.05 & 1.43 \\
\hline BCR & 1.72 & 1.35 & 1.15 & 0.98 & 0.25 & 1.39 & 0.09 & 1.55 & 0.59 & 1.24 & 1.02 & 0.74 & 1.76 & 1.13 \\
\hline Nordea & 2.67 & 2.30 & 2.10 & 1.94 & 1.21 & 2.35 & 1.05 & 2.50 & 1.54 & 2.19 & 1.97 & 1.69 & 2.71 & 2.09 \\
\hline NLB SI & 2.20 & 1.83 & 1.64 & 1.47 & 0.74 & 1.88 & 0.58 & 2.03 & 1.07 & 1.73 & 1.51 & 1.23 & 2.25 & 1.62 \\
\hline VUB SK & 1.93 & 1.56 & 1.37 & 1.20 & 0.47 & 1.61 & 0.31 & 1.76 & 0.80 & 1.45 & 1.23 & 0.95 & 1.97 & 1.35 \\
\hline HSBC & 1.66 & 1.28 & 1.09 & 0.92 & 0.19 & 1.33 & 0.03 & 1.49 & 0.53 & 1.18 & 0.96 & 0.68 & 1.70 & 1.07 \\
\hline
\end{tabular}

Source: Authors' calculations.

In each row, we predict the (hypothetical) OSII buffer of the largest bank in a particular country (e.g. Erste Group) based on the OLS estimation results with OSII score and country dummies (see Table 6 first column). In the diagonal elements, the OSII buffer of a bank in its home country is predicted (e.g. Erste Group in AT). In the off-diagonal elements, the hypothetical prediction of a particular bank for all other European union member states is calculated (e.g. Erste Group in BE, BG, ect.). We cut the matrix in two parts after the "HU column" to improve readability. The diagonal elements are highlighted in bold characters. 
Table 8: OLS prediction of bank's OSII buffer in different countries

\begin{tabular}{|c|c|c|c|c|c|c|c|c|c|c|c|c|c|c|}
\hline & IE & IS & IT & LT & $\mathrm{LU}$ & MT & $\mathrm{NL}$ & $\mathrm{PL}$ & $\mathrm{PT}$ & $\mathrm{RO}$ & $\mathrm{SE}$ & SI & SK & UK \\
\hline Erste Group & 1.18 & 1.86 & 0.83 & 1.80 & 1.40 & 1.65 & 1.77 & 1.07 & 1.02 & 1.79 & 2.00 & 0.90 & 1.31 & 0.83 \\
\hline BNP BE & 1.21 & 1.89 & 0.86 & 1.83 & 1.43 & 1.68 & 1.80 & 1.10 & 1.05 & 1.82 & 2.03 & 0.93 & 1.34 & 0.86 \\
\hline UC Bulbank & 0.97 & 1.65 & 0.63 & 1.60 & 1.19 & 1.45 & 1.57 & 0.86 & 0.82 & 1.59 & 1.79 & 0.69 & 1.11 & 0.63 \\
\hline BOC & 1.42 & 2.10 & 1.07 & 2.05 & 1.64 & 1.89 & 2.02 & 1.31 & 1.27 & 2.04 & 2.24 & 1.14 & 1.56 & 1.08 \\
\hline CSOB CZ & 1.02 & 1.70 & 0.67 & 1.65 & 1.24 & 1.49 & 1.61 & 0.91 & 0.87 & 1.63 & 1.84 & 0.74 & 1.16 & 0.68 \\
\hline DB & 1.30 & 1.98 & 0.96 & 1.93 & 1.52 & 1.77 & 1.90 & 1.19 & 1.15 & 1.92 & 2.12 & 1.02 & 1.44 & 0.96 \\
\hline Dankse Bank & 2.10 & 2.78 & 1.75 & 2.73 & 2.32 & 2.57 & 2.69 & 1.99 & 1.94 & 2.71 & 2.92 & 1.82 & 2.23 & 1.75 \\
\hline Swedbank & 1.37 & 2.05 & 1.03 & 2.00 & 1.59 & 1.84 & 1.97 & 1.26 & 1.22 & 1.99 & 2.19 & 1.09 & 1.51 & 1.03 \\
\hline Santander & 1.88 & 2.56 & 1.53 & 2.51 & 2.10 & 2.35 & 2.47 & 1.77 & 1.72 & 2.49 & 2.70 & 1.60 & 2.01 & 1.54 \\
\hline OP Group & 1.13 & 1.81 & 0.78 & 1.76 & 1.35 & 1.60 & 1.73 & 1.02 & 0.98 & 1.74 & 1.95 & 0.85 & 1.27 & 0.79 \\
\hline BNP FR & 1.16 & 1.84 & 0.81 & 1.79 & 1.38 & 1.63 & 1.76 & 1.05 & 1.01 & 1.78 & 1.98 & 0.88 & 1.30 & 0.82 \\
\hline BOG & 1.51 & 2.19 & 1.17 & 2.14 & 1.74 & 1.99 & 2.11 & 1.40 & 1.36 & 2.13 & 2.34 & 1.24 & 1.65 & 1.17 \\
\hline Zagrebacka & 1.35 & 2.03 & 1.01 & 1.98 & 1.58 & 1.83 & 1.95 & 1.24 & 1.20 & 1.97 & 2.18 & 1.08 & 1.49 & 1.01 \\
\hline OTP HU & 1.39 & 2.07 & 1.05 & 2.02 & 1.61 & 1.87 & 1.99 & 1.28 & 1.24 & 2.01 & 2.21 & 1.11 & 1.53 & 1.05 \\
\hline BOI & 1.06 & 1.74 & 0.71 & 1.69 & 1.28 & 1.53 & 1.66 & 0.95 & 0.91 & 1.68 & 1.88 & 0.78 & 1.20 & 0.72 \\
\hline Landsbankinn IS & 1.43 & 2.11 & 1.08 & 2.06 & 1.65 & 1.90 & 2.02 & 1.32 & 1.27 & 2.04 & 2.25 & 1.15 & 1.56 & 1.09 \\
\hline Unicredit S.p.A & 1.67 & 2.36 & 1.33 & 2.30 & 1.90 & 2.15 & 2.27 & 1.56 & 1.52 & 2.29 & 2.50 & 1.40 & 1.81 & 1.33 \\
\hline AB SEB bank & 1.84 & 2.52 & 1.49 & 2.47 & 2.06 & 2.31 & 2.43 & 1.73 & 1.68 & 2.45 & 2.66 & 1.56 & 1.97 & 1.50 \\
\hline Societe Generale Bank LU & 0.78 & 1.46 & 0.44 & 1.41 & 1.01 & 1.26 & 1.38 & 0.67 & 0.63 & 1.40 & 1.61 & 0.50 & 0.92 & 0.44 \\
\hline $\mathrm{BOV}$ & 1.14 & 1.82 & 0.79 & 1.76 & 1.36 & 1.61 & 1.73 & 1.03 & 0.98 & 1.75 & 1.96 & 0.86 & 1.27 & 0.79 \\
\hline ING Bank NL & 1.67 & 2.35 & 1.32 & 2.30 & 1.89 & 2.14 & 2.26 & 1.56 & 1.51 & 2.28 & 2.49 & 1.39 & 1.80 & 1.32 \\
\hline PKO BP & 0.82 & 1.50 & 0.48 & 1.45 & 1.05 & 1.30 & 1.42 & 0.71 & 0.67 & 1.44 & 1.65 & 0.55 & 0.96 & 0.48 \\
\hline Caixa & 1.19 & 1.87 & 0.85 & 1.82 & 1.41 & 1.66 & 1.79 & 1.08 & 1.04 & 1.81 & 2.01 & 0.91 & 1.33 & 0.85 \\
\hline BCR & 0.90 & 1.58 & 0.55 & 1.52 & 1.12 & 1.37 & 1.49 & 0.79 & 0.74 & 1.51 & 1.72 & 0.62 & 1.03 & 0.55 \\
\hline Nordea & 1.85 & 2.53 & 1.50 & 2.48 & 2.07 & 2.32 & 2.45 & 1.74 & 1.70 & 2.47 & 2.67 & 1.57 & 1.99 & 1.51 \\
\hline NLB SI & 1.38 & 2.06 & 1.04 & 2.01 & 1.61 & 1.86 & 1.98 & 1.27 & 1.23 & 2.00 & 2.21 & 1.11 & 1.52 & 1.04 \\
\hline VUB SK & 1.11 & 1.79 & 0.76 & 1.74 & 1.33 & 1.58 & 1.71 & 1.00 & 0.96 & 1.73 & 1.93 & 0.83 & 1.25 & 0.77 \\
\hline HSBC & 0.84 & 1.52 & 0.49 & 1.46 & 1.06 & 1.31 & 1.43 & 0.73 & 0.68 & 1.45 & 1.66 & 0.56 & 0.97 & 0.49 \\
\hline
\end{tabular}

See table notes under Table 7

\section{Conclusion}

In this paper, to the best of our knowledge, we present a first empirical analysis of how European union member states calibrate their buffer rates for other systemically important institutions. Given the fact that the identification of OSIIs via the OSII score calculation is based on the unified approach by EBA (2014) (see Table 1) our results on the OSII buffer assignment are quite surprising. The OSII buffers are very different across countries. Although the OSII score has the expected positive coefficient, implying that on average banks with a higher OSII score receive a higher OSII buffer, the country specific dummies are more important. A different degree of regulatory capture and/or different preferences of the national regulators in the OSII assignment process might be a potential explanation for this finding. We also show that there is probably a missing link in the recommendation by EBA (2014) of how to translate the OSII scores into OSII buffers.

Our analysis reveals that each country in the European union judges the risks to financial stability stemming from the failure of an OSII quite differently. All provided estimation results lead to this conclusion. Alternatively, one could speculate on other motives, which would cause a national regulator to assign a lower buffer than prudent countries would have assigned. A possible motive for a low OSII buffer could be that a bank should not breach the minimum regulatory capital requirements. We also provide evidence that there is different degree of regulatory capture in all countries following the qualitative 
approach by Carpenter (2014) step-by-step. For example, many countries have not yet implemented the SyRB, which also a macroprudential tool to address the too-big-to-fail dilemma, or set very low SyRBs. In some countries, the ESRB recommendation (ESRB, 2011b) to establish a macroprudential authority has been ignored or the independence of such an authority is questionable.

In this context, we also suggest to follow the recommendation by ESRB (2011a) that the national central bank should have a leading role in macro-prudential oversight. Central banks as the leading macroprudential authority assign a $0.5 p p$ higher OSII buffer on average than other macroprudential authorities.

The results of our paper have already initialized (emergency) activities by the European Central bank and by the ESRB. A new working group has started to work on unifying the OSII buffer assignment process to reduce the amount of country heterogeneity starting in 2019. After all, the credibility of macroprudential regulation is at stake and currently regulatory arbitrage by moving the headquarter of large banking groups is possible.

As the OSII buffer is designed to address idiosyncratic risks stemming from a particular bank ("caused losses”), we would suggest to quantify the risk more directly as suggested by Siebenbrunner et al. (2017). In their model different contagion losses are calculated based on the interbank network in Austria. After quantifying contagion losses based on the hypothetical failure of an OSII, a prudent regulator would then look at the relationship between capital ratios and probability of a bank failure and calibrate the OSII buffer accordingly. Exactly this idea suggested formulated by FED (2015). In case that the interbank network of banks is not available, Siebenbrunner et al. (2017) also confirm that the variables in the scoring approach by EBA (2014) are still very useful to predict contagion losses as a second best option. Based on the approach by FED (2015), Passmore and von Hafften (2019) show that the current maximum OSII buffers (also the buffers for globally important banks) would have been too small based on the experience of the 2007/08 financial crisis for the US banks. They suggest to raise capital requirements 5.50 to 8.25 percentage points for banks currently subject to surcharges.

Finally, we make a case for a unified OSII scoring and assignment process across all EU countries to ensure a level playing field for all OSIIs in the European union. This claim relies on the analysis of the structural parameters of the bargaining process and the country-by-country estimation results. If regulators and policy maker cannot agree on such a unified assignment process, which is very likely, any form of minimum standards (e.g. an OSII score of 1500 would require an OSII buffer of 1.5\%) would improve the bargaining power of the regulator or make their preferences on an OSII buffer given the same OSII score more similar.

\section{Acknowledgements}

I am grateful to Mathias Schaller (OeNB) and Melanie Nachreiner (OeNB) for valueable research assistance and the R-codes for the figures. Peter Strobl (OeNB) helped me with all the regulatory details. I also received very useful comments from the participants of "the $7^{\text {th }}$ EBA Policy Research Workshop reaping the benefits of an integrated EU banking sector (2018)" and three anonymous referees. I would 
like to address particular words of thanks to Kim Abildgren (Danmarks Nationalbank) for discussing our paper and providing many helpful remarks at the $7^{\text {th }}$ EBA Policy Research Workshop.

\section{References}

Acharya, V. V., Pedersen, L. H., Philippon, T., and Richardson, M. (2017). Measuring systemic risk. Review of Financial Studies, 30(1):2-47.

Adrian, T. and Brunnermeier, M. K. (2016). CoVaR. American Economic Review, 106(7):1705-1741.

BIS (2012). A framework for dealing with domestic systemically important banks. Basel committee on banking supervision publication, Basel Committee on Banking Supervision.

BIS (2013). Global systemically important banks: updated assessment methodology and the higher loss absorbency requirement. Basel committee on banking supervision publication, Basel Committee on Banking Supervision.

Brownlees, C. and Engle, R. F. (2016). SRISK: A conditional capital shortfall measure of systemic risk. Review of Financial Studies, 30(1):48-79.

Calomiris, C. W. and Haber, S. H. (2015). Fragile by design: The political origins of banking crises and scarce credit. Princeton University Press.

Cameron, C. and Trivedi, P. (2005). Microeconometrics: Methods and Applications. Camebridge University Press.

Carpenter, D. (2014). Detecting and measuring capture. In Carpenter, D. and Moss, D., editors, Preventing Regulatory Capture - Special Interest Influence and How to Limit It, chapter 3, pages 57-68. Cambridge University Press.

Carroll, N. (2017). oglmx: Estimation of Ordered Generalized Linear Models. R package version 2.0.0.3.

Chakrabarty, B. and Zhang, G. (2012). Credit contagion channels: Market microstructure evidence from lehman brothers' bankruptcy. Financial Management, 41(2):320-343.

Dumontaux, N. and Pop, A. (2013). Understanding the market reaction to shockwaves: Evidence from the failure of lehman brothers. Fournal of Financial Stability, 9(3):269-286.

EBA (2014). On the criteria to determine the conditions of application of Article 131(3) of Directive 2013/36/EU (CRD) in relation to the assessment of other systemically important institutions (O-SIIs). Eba guideline, European Banking Authority.

ECB (December 2009). European Central Bank. Financial Stability Review.

Engle, R., Jondeau, E., and Rockinger, M. (2014). Systemic risk in europe. Review of Finance, 19(1):145190. 
ESRB (2011a). Recommendation of the european systemic risk board of 21 september 2011 on lending in foreign currencies. Technical Report ESRB/2011/1, European Systemic Risk Board. Frankfurt.

ESRB (2011b). Recommendation of the european systemic risk board of 22 december 2011 on the macroprudential mandate of national authorities. Technical Report ESRB/2011/3, European Systemic Risk Board. Frankfurt.

Eurostat (2015). EUROSTAT SUPPLEMENTARY TABLE FOR REPORTING GOVERNMENT INTERVENTIONS TO SUPPORT FINANCIAL INSTITUTIONS. Background note, Eurostat.

Eurostat (2018). Eurostat Supplementary Table for Reporting Government Interventions to Support financial Institutions. Background note, Eurostat.

FED (2015). Calibrating the GSIB Surcharge. Fed publication, Board of Governors of the Federal Reserve System.

Harrell, F. E. (2018). rms: Regression Modeling Strategies. R package version 5.1-2.

Howarth, D. and Quaglia, L. (2014). The steep road to European banking union: Constructing the single resolution mechanism. Fournal of Common Market Studies, 52:125-140.

Igan, D. O., Lambert, T., et al. (2019). Bank lobbying: regulatory capture and beyond. IMF Working Paper, No. 19/171.

Iori, G., Jafarey, S., and Padilla, F. G. (2006). Systemic risk on the interbank market. Fournal of Economic Behavior and Organization, 61(4):525-542.

Ivashina, V. and Scharfstein, D. (2010). Bank lending during the financial crisis of 2008. Fournal of Financial economics, 97(3):319-338.

Kaufmann, D., Kraay, A., and Mastruzzi, M. (2011). The worldwide governance indicators: methodology and analytical issues. Hague fournal on the Rule of Law, 3(2):220-246.

Kern, A. (2015). European banking union: a legal and institutional analysis of the single supervisory mechanism and the single resolution mechanism. European Law Review, (2):154-187.

Kleiber, K. and Zeileis, A. (2008). Applied Econometrics with R. Springer-Verlag, New York. ISBN 978-0387-77316-2.

Laffont, J.-J. and Tirole, J. (1991). The politics of government decision-making: A theory of regulatory capture. The quarterly journal of economics, 106(4):1089-1127.

McFadden, D. et al. (1977). Quantitative methods for analyzing travel behavior of individuals: some recent developments. Institute of Transportation Studies, University of California Berkeley.

Nash, J. (1953). Two-person cooperative games. Econometrica: Journal of the Econometric Society, pages $128-140$. 
Passmore, W. and von Hafften, A. (2019). Are Basel's Capital Surcharges for Global Systemically Important Banks Too Small? International fournal of Central Banking, 15(1):107-156.

Pissarides, C. A. (2000). Equilibrium unemployment theory. MIT press.

Rime, B. (2001). Capital requirements and bank behaviour: Empirical evidence for switzerland. Fournal of Banking \& Finance, 25(4):789-805.

Schuknecht, L. and Siegerink, V. (2020). The political economy of the g20 agenda on financial regulation. European fournal of Political Economy, 65:101941.

Siebenbrunner, C., Sigmund, M., and Kerbl, S. (2017). Can bank-specific variables predict contagion effects? Quantitative Finance, 17(12):1805-1832.

Silvapulle, M. J. and Sen, P. K. (2005). Constrained statistical inference: Inequality, order and shape restrictions. John Wiley \& Sons.

Stigler, G. J. (1971). The theory of economic regulation. The Bell fournal of Economics and Management Science, 2(1):3-21.

Süli, E. and Mayers, D. F. (2003). An introduction to numerical analysis. Cambridge university press.

Vanbrabant, L. (2020). restriktor: Restricted Statistical Estimation and Inference for Linear Models. R package version $0.2-800$.

Venables, W. N. and Ripley, B. D. (2002). Modern Applied Statistics with S. Springer, New York, fourth edition. ISBN 0-387-95457-0.

Wheelock, D. and Wilson, P. (2000). Why do banks disappear? the determinants of u.s. bank failures and acquisitions. The Review of Economics and Statistics, 82(1):127-138.

Wooldridge, J. M. (2002). Econometric Analysis of Cross Section and Panel Data. The MIT Press, Cambridge, MA. 


\section{Appendix A. Summary Statistics}

Table A.9: Summary statistics of included variables

\begin{tabular}{|l|r|r|r|r|r|r|r|r|}
\hline Variables & Min. & 1st Qu. & Median & Mean & 3rd Qu. & Max & Variance & Data.Cov \\
\hline Target O-SII Buffer & 0.00 & 0.25 & 0.75 & 0.84 & 1.00 & 2.00 & 0.43 & 100.00 \\
OSII Score & 0.09 & 3.70 & 7.13 & 10.98 & 16.18 & 49.69 & 88.86 & 100.00 \\
Original OSII Score & 9.00 & 370.00 & 713.00 & 1098.00 & 1618.00 & 4969.00 & 888579.99 & 100.00 \\
Target SyRB & 0.00 & 0.00 & 0.50 & 0.99 & 2.00 & 3.00 & 1.43 & 100.00 \\
Tier 1 Ratio (-1) & 7.01 & 14.10 & 16.08 & 18.97 & 19.78 & 104.90 & 104.53 & 83.51 \\
Control of Corruption (-1) & -0.25 & 0.23 & 0.93 & 1.03 & 1.84 & 2.24 & 0.60 & 100.00 \\
Operating Income (-1) & -0.75 & 1.78 & 2.65 & 2.84 & 3.83 & 7.03 & 2.03 & 86.89 \\
Mapru by CB & 0.00 & 0.00 & 1.00 & 0.69 & 1.00 & 1.00 & 0.21 & 100.00 \\
\hline
\end{tabular}

Source: ESRB, SNL and Worldwide governance indicators (Kaufmann et al., 2011).

This table reports the minimum, the first quantile, the median, the mean, the third quantile, the maximum and the data coverage (Data Cov.) for the EU OSII data between 2015 and 2018 with 473 observations.

We rescale the OSII score to be between 0 and 100 to measure it on the same scale as the OSII buffer and the SyRB.

OSII buffer, OSII score, SyRB, Tier 1 ratio (-1) and operating income ratio (-1) are given in \%-values.

Control of Corruption (-1) is a standard normal random variable, i.e. with zero mean, unit standard deviation and ranging approximately from -2.5 to 2.5 .

Mapru by CB is set to 1 for all banks in BE, CY, CZ, EE, FI, FR, GR, HU, IE, LT, MT, NL, PT, RO, SE, SK and additionally for AT, BG, DE, LV and SI.

The Mapru by CB is based on the ESRB classification and on information which regulatory institution writes the first draft of the legal opinion on the OSII buffer.

\section{Appendix B. Poisson Count Data Estimation Results}

In this section, we present four estimation results based on the Poisson count data model. The results of the second model are used to calculate the capital requirement simulation in Section 4.2. Overall, the results in Table B.10 are in line with Table 4 and Table 6.

Again, we are able to confirm country heterogeneity in the OSII buffer assignment and most of the other results described in Section 5.3. A higher control of corruption and the central bank as the macroprudential increase the OSII buffers by an economically and statistically significant amount. 
Table B.10: Poisson Count Models

\begin{tabular}{|c|c|c|c|c|}
\hline & Score & Score and Country Dummies & Regulatory Capture & Mapru by $\mathrm{CB}$ \\
\hline Intercept & $\begin{array}{l}0.8970^{* * *} \\
(0.0982)\end{array}$ & $\begin{array}{l}1.3456^{* * * *} \\
(0.0963)\end{array}$ & $\begin{array}{c}0.2292 \\
(0.7438)\end{array}$ & $\begin{array}{c}-0.1408 \\
(0.1807)\end{array}$ \\
\hline \multirow[t]{2}{*}{ OSII Score } & $0.0383^{* * *}$ & $0.0376^{* * *}$ & $0.0267^{* * *}$ & $0.0318^{* * *}$ \\
\hline & $(0.0033)$ & $(0.0027)$ & $(0.0029)$ & $(0.0030)$ \\
\hline Target SyRB & & & $\begin{array}{l}0.3118^{* * *} \\
(0.0676)\end{array}$ & $\begin{array}{l}0.1509^{* * * *} \\
(0.0270)\end{array}$ \\
\hline \multirow[t]{2}{*}{ Tier 1 Ratio $(-1)$} & & & $-0.0088^{* *}$ & -0.0058 \\
\hline & & & $(0.0031)$ & $(0.0034)$ \\
\hline \multirow[t]{2}{*}{ Operating Income (-1) } & & & $0.0590^{*}$ & $0.1266^{* * *}$ \\
\hline & & & $(0.0233)$ & $(0.0256)$ \\
\hline \multirow[t]{2}{*}{ Control of Corruption $(-1)$} & & & 0.4521 & $0.1784^{* * *}$ \\
\hline & & & $(0.4952)$ & $(0.0442)$ \\
\hline \multirow[t]{2}{*}{ Mapru by $\mathrm{CB}$} & & & & $0.5154^{* * *}$ \\
\hline & & & & $(0.0878)$ \\
\hline \multirow[t]{2}{*}{$\mathrm{BE}$} & & $-0.3261^{* * *}$ & $0.3113^{*}$ & \\
\hline & & $(0.0559)$ & $(0.1430)$ & \\
\hline BG & & $-0.5038^{* * *}$ & -0.2238 & \\
\hline & & $(0.0598)$ & $(0.8607)$ & \\
\hline $\mathrm{CY}$ & & $-0.7482^{* * *}$ & 0.2204 & \\
\hline & & $(0.1457)$ & $(0.4014)$ & \\
\hline $\mathrm{CZ}$ & & $-19.0473^{* * *}$ & $-19.7812^{* * *}$ & \\
\hline & & $(0.2774)$ & $(0.5804)$ & \\
\hline $\mathrm{DE}$ & & $-0.2508^{* * *}$ & -0.1461 & \\
\hline & & $(0.0597)$ & $(0.1796)$ & \\
\hline DK & & $-19.2449^{* * *}$ & $-20.4779^{* * *}$ & \\
\hline & & $(0.5402)$ & $(0.6375)$ & \\
\hline $\mathrm{EE}$ & & $-0.2527^{*}$ & -0.1254 & \\
\hline & & $(0.1094)$ & $(0.2149)$ & \\
\hline ES & & $-1.3838^{* * *}$ & -0.3772 & \\
\hline & & $(0.0833)$ & $(0.5033)$ & \\
\hline FI & & $-0.4119^{*}$ & -0.4660 & \\
\hline & & $(0.1661)$ & $(0.3715)$ & \\
\hline FR & & $-0.6223^{* * *}$ & 0.0540 & \\
\hline & & $(0.0609)$ & $(0.1825)$ & \\
\hline GR & & $-0.8845^{* * *}$ & 0.5259 & \\
\hline & & $(0.0757)$ & $(0.8129)$ & \\
\hline $\mathrm{HR}$ & & 0.0014 & 0.2202 & \\
\hline & & $(0.1033)$ & $(0.6632)$ & \\
\hline $\mathrm{HU}$ & & $-0.5451^{* * *}$ & 0.4055 & \\
\hline & & $(0.0837)$ & $(0.7212)$ & \\
\hline IE & & $-0.8487^{* * *}$ & $-0.5045^{*}$ & \\
\hline & & $(0.1697)$ & $(0.2309)$ & \\
\hline IS & & $-0.3391^{* * *}$ & $-0.7479^{* * *}$ & \\
\hline & & $(0.0685)$ & $(0.2088)$ & \\
\hline IT & & $-1.2709^{* * *}$ & -0.0382 & \\
\hline & & $(0.0665)$ & $(0.7146)$ & \\
\hline LT & & $-0.3422^{*}$ & 0.7412 & \\
\hline & & $(0.1420)$ & $(0.4977)$ & \\
\hline LU & & $-0.5902^{* * *}$ & -0.4698 & \\
\hline & & $(0.1624)$ & $(0.2822)$ & \\
\hline MT & & -0.3021 & 0.6806 & \\
\hline & & $(0.1723)$ & $(0.3612)$ & \\
\hline NL & & -0.2972 & $-0.6157^{*}$ & \\
\hline & & $(0.1561)$ & $(0.2844)$ & \\
\hline PL & & $-1.1975^{* * *}$ & $-1.2682^{* *}$ & \\
\hline & & $(0.1272)$ & $(0.4319)$ & \\
\hline PT & & $-1.0209^{* * *}$ & -0.2828 & \\
\hline & & $(0.0638)$ & $(0.3257)$ & \\
\hline RO & & -0.1181 & 0.5589 & \\
\hline & & $(0.0755)$ & $(0.7770)$ & \\
\hline SE & & -0.2276 & -0.6159 & \\
\hline & & $(0.1482)$ & $(0.3527)$ & \\
\hline SI & & $-1.3835^{* * *}$ & -0.5003 & \\
\hline & & $(0.1032)$ & $(0.3873)$ & \\
\hline SK & & $-0.6029^{* * *}$ & 0.0169 & \\
\hline & & $(0.1019)$ & $(0.6537)$ & \\
\hline UK & & $-2.8750^{* * *}$ & $-1.8919^{* *}$ & \\
\hline & & $(0.5628)$ & $(0.5889)$ & \\
\hline Year 2016 & -0.1833 & -0.0367 & -0.0319 & 0.0262 \\
\hline & $(0.1180)$ & $(0.0943)$ & $(0.0822)$ & (0.1194) \\
\hline Year 2017 & $-0.1992^{*}$ & -0.0164 & -0.0189 & -0.0800 \\
\hline & $(0.0956)$ & $(0.0912)$ & $(0.0825)$ & $(0.1079)$ \\
\hline Year 2018 & $-0.1962^{*}$ & -0.0235 & 0.0180 & -0.0341 \\
\hline & $(0.0968)$ & $(0.0858)$ & $(0.0740)$ & $(0.1102)$ \\
\hline Number of Obs. & 473 & 473 & 389 & 389 \\
\hline Residual Deviance & 837.86 & 295.80 & 206.33 & 526.75 \\
\hline AIC & 2067.54 & 1579.47 & 1331.88 & 1600.29 \\
\hline McFadden $\mathrm{R}^{2}$ & 0.12 & 0.35 & 0.34 & 0.17 \\
\hline
\end{tabular}




\section{Appendix C. Estimation results without banks from $\mathrm{CZ}$ and DK}

In this section, we re-estimate Eq. (E.4) excluding banks from the Czech Republic and Denmark. These two countries have not yet assigned positive OSII buffers to their OSIIs. Interestingly, in the Czech Republic, the OSII methodology EBA (2014) is applied but instead of assigning an OSII buffer, the OSII score is used to assign a SyRB to some banks. We only report the OLS results which are compareable to Table 6. 
Table C.11: OLS Estimation without CZ and DK banks

\begin{tabular}{|c|c|c|c|c|}
\hline & Score & Score and Country Dummies & Regulatory Capture & Mapru by $\mathrm{CB}$ \\
\hline Intercept & $\begin{array}{l}0.5363^{* * *} \\
(0.0992)\end{array}$ & $\begin{array}{l}1.0613^{* * *} \\
(0.1048)\end{array}$ & $\begin{array}{c}-0.1610 \\
(0.8473)\end{array}$ & $\begin{array}{c}-0.3672^{* *} \\
(0.1405)\end{array}$ \\
\hline OSII Score & $\begin{array}{l}0.0429^{* * *} \\
(0.0025)\end{array}$ & $\begin{array}{l}0.0406^{* * *} \\
(0.0020)\end{array}$ & $\begin{array}{l}0.0296^{* * *} \\
(0.0021)\end{array}$ & $\begin{array}{l}0.0359^{* * * *} \\
(0.0022)\end{array}$ \\
\hline Target SyRB & & & $\begin{array}{l}0.3866^{* * * *} \\
(0.0419)\end{array}$ & $\begin{array}{l}0.2041^{* * *} \\
(0.0194)\end{array}$ \\
\hline Tier 1 Ratio $(-1)$ & & & $\begin{array}{r}-0.0042^{*} \\
(0.0017)\end{array}$ & $\begin{array}{c}-0.0037 \\
(0.0021)\end{array}$ \\
\hline Control of Corruption (-1) & & & $\begin{array}{c}0.4651 \\
(0.5548)\end{array}$ & $\begin{array}{l}0.2115^{* * *} \\
(0.0371)\end{array}$ \\
\hline Operating Income (-1) & & & $\begin{array}{r}0.0433^{*} \\
(0.0183)\end{array}$ & $\begin{array}{l}0.0837^{* * *} \\
(0.0213)\end{array}$ \\
\hline Mapru by $\mathrm{CB}$ & & & & $\begin{array}{l}0.3860^{* * *} \\
(0.0492)\end{array}$ \\
\hline $\mathrm{BE}$ & & $\begin{array}{c}-0.3878^{* * *} \\
(0.0938)\end{array}$ & $\begin{array}{c}0.2731^{*} \\
(0.1144)\end{array}$ & \\
\hline BG & & $\begin{array}{l}-0.5761^{* * *} \\
(0.0970)\end{array}$ & $\begin{array}{c}-0.4379 \\
(0.9600)\end{array}$ & \\
\hline $\mathrm{CY}$ & & $\begin{array}{c}-0.7354^{* * *} \\
(0.1057)\end{array}$ & $\begin{array}{c}0.2366 \\
(0.4186)\end{array}$ & \\
\hline $\mathrm{DE}$ & & $\begin{array}{l}-0.3061^{* * * *} \\
(0.0887)\end{array}$ & $\begin{array}{c}-0.2171 \\
(0.1922)\end{array}$ & \\
\hline $\mathrm{EE}$ & & $\begin{array}{c}-0.2042 \\
(0.1314)\end{array}$ & $\begin{array}{c}-0.2174 \\
(0.1944)\end{array}$ & \\
\hline ES & & $\begin{array}{c}-1.1463^{* * *} \\
(0.1088)\end{array}$ & $\begin{array}{c}-0.1210 \\
(0.5646)\end{array}$ & \\
\hline FI & & $\begin{array}{c}-0.4879^{* *} \\
(0.1783)\end{array}$ & $\begin{array}{c}-0.5290 \\
(0.4411)\end{array}$ & \\
\hline FR & & $\begin{array}{c}-0.7134^{* * *} \\
(0.1070)\end{array}$ & $\begin{array}{c}0.0198 \\
(0.1705)\end{array}$ & \\
\hline GR & & $\begin{array}{l}-1.0368^{* * * *} \\
(0.1243)\end{array}$ & $\begin{array}{c}0.4537 \\
(0.9201)\end{array}$ & \\
\hline HR & & $\begin{array}{c}0.0393 \\
(0.0969)\end{array}$ & $\begin{array}{c}0.1912 \\
(0.7407)\end{array}$ & \\
\hline $\mathrm{HU}$ & & $\begin{array}{c}-0.5852^{* * *} \\
(0.1090)\end{array}$ & $\begin{array}{c}0.4462 \\
(0.8042)\end{array}$ & \\
\hline IE & & $\begin{array}{c}-0.8189^{* * *} \\
(0.1034)\end{array}$ & $\begin{array}{c}-0.2916^{*} \\
(0.1240)\end{array}$ & \\
\hline IS & & $\begin{array}{c}-0.1992 \\
(0.1555)\end{array}$ & $\begin{array}{c}-0.7913^{* *} \\
(0.2552)\end{array}$ & \\
\hline IT & & $\begin{array}{c}-1.1969^{* * *} \\
(0.1265)\end{array}$ & $\begin{array}{c}0.0777 \\
(0.8081)\end{array}$ & \\
\hline LT & & $\begin{array}{c}-0.2316 \\
(0.1377)\end{array}$ & $\begin{array}{c}0.9592 \\
(0.5283)\end{array}$ & \\
\hline LU & & $\begin{array}{c}-0.5834^{* * *} \\
(0.1191)\end{array}$ & $\begin{array}{c}-0.3609 \\
(0.3068)\end{array}$ & \\
\hline MT & & $\begin{array}{r}-0.3695^{*} \\
(0.1458)\end{array}$ & $\begin{array}{c}0.7181 \\
(0.4333)\end{array}$ & \\
\hline NL & & $\begin{array}{c}-0.2423 \\
(0.1526)\end{array}$ & $\begin{array}{c}-0.6957^{* *} \\
(0.2582)\end{array}$ & \\
\hline PL & & $\begin{array}{c}-0.9235^{* * *} \\
(0.0997)\end{array}$ & $\begin{array}{c}-1.2056^{* *} \\
(0.4622)\end{array}$ & \\
\hline PT & & $\begin{array}{l}-0.9882^{* * *} \\
(0.1187)\end{array}$ & $\begin{array}{c}-0.1987 \\
(0.3694)\end{array}$ & \\
\hline RO & & $\begin{array}{c}-0.2002^{*} \\
(0.0946)\end{array}$ & $\begin{array}{c}0.5016 \\
(0.8674)\end{array}$ & \\
\hline SE & & $\begin{array}{c}-0.0467 \\
(0.1227)\end{array}$ & $\begin{array}{c}-0.6316 \\
(0.3758)\end{array}$ & \\
\hline SI & & $\begin{array}{l}-1.1064^{* * *} \\
(0.1157)\end{array}$ & $\begin{array}{c}-0.1878 \\
(0.4129)\end{array}$ & \\
\hline SK & & $\begin{array}{c}-0.7004^{* * *} \\
(0.1259)\end{array}$ & $\begin{array}{c}-0.0824 \\
(0.7337)\end{array}$ & \\
\hline UK & & $\begin{array}{c}-1.1469^{* * *} \\
(0.0868)\end{array}$ & $\begin{array}{l}-0.7456^{* * * *} \\
(0.2180)\end{array}$ & \\
\hline Year 2016 & $\begin{array}{c}-0.0809 \\
(0.1069)\end{array}$ & $\begin{array}{c}-0.0479 \\
(0.0819)\end{array}$ & $\begin{array}{c}-0.0464 \\
(0.0837)\end{array}$ & $\begin{array}{c}0.1069 \\
(0.0999)\end{array}$ \\
\hline Year 2017 & $\begin{array}{c}-0.1527 \\
(0.1011)\end{array}$ & $\begin{array}{c}-0.0346 \\
(0.0754)\end{array}$ & $\begin{array}{c}-0.0469 \\
(0.0786)\end{array}$ & $\begin{array}{c}-0.0308 \\
(0.0939)\end{array}$ \\
\hline Year 2018 & $\begin{array}{c}-0.1509 \\
(0.1008)\end{array}$ & $\begin{array}{c}-0.0440 \\
(0.0746)\end{array}$ & $\begin{array}{c}-0.0089 \\
(0.0753)\end{array}$ & $\begin{array}{c}0.0198 \\
(0.0941)\end{array}$ \\
\hline R-squared & 0.3993 & 0.7640 & 0.8105 & 0.5973 \\
\hline Adj. R-squared & 0.3940 & 0.7478 & 0.7919 & 0.5873 \\
\hline Number of obs. & 453.0000 & 453.0000 & 371.0000 & 371.0000 \\
\hline
\end{tabular}

${ }^{* * *} p<0.001,{ }^{* *} p<0.01,{ }^{*} p<0.05$.

Source: Authors' calculations.

This table shows the results of estimating Eq. (E.5). The dependent variable is the OSII buffer.

The estimation results should be compared to Table 6 . 


\section{Appendix D. OSII Buffer Assignment - Accounting for being a subsidiary}

As discussed in Section 2, 77 OSIIs are owned by another European OSII. Therefore, we add a subsidiary dummy to account for this ownership structure. By comparing Table 6 with Table D.12, the subsidiary dummy is not significant and the other coefficients are almost unchanged. We conclude that $\S 8$ of Article 131 of Directive 2013/36/EU (CRD) has not significantly influenced the OSII buffer assignment for OSIIs that are subsidiaries of European banks. As mentioned in Section 2, in the new CRD V, §8 will be replaced by the following legislation:

Without prejudice to Article 133 and paragraph 5 of this Article, where an OSII is a subsidiary of either a GSII or an OSII which is either an institution or a group headed by an EU parent institution, and subject to an OSII buffer on a consolidated basis, the buffer that applies on an individual or sub-consolidated basis for the OSII shall not exceed the lower of:

1. the sum of the higher of the GSII or the OSII buffer rate applicable to the group on a consolidated basis and $1 \%$ of the total risk exposure amount calculated in accordance with Article 92(3) of Regulation (EU) No 575/2013; and

2. 3\% of the total risk exposure amount calculated in accordance with Article 92(3) of Regulation (EU) No 575/2013, or the rate the Commission has authorized to be applied to the group on a consolidated basis in accordance with paragraph $5 \mathrm{a}$ of this Article.

In other words, the OSII buffer on the sub-consolidated level is now allowed to exceed the OSII buffer of the parent (consolidated) level. 
Table D.12: OLS Nash Bargaining Solution: Subsidiaries

\begin{tabular}{|c|c|c|c|c|}
\hline & Score & Score and Country Dummies & Regulatory Capture & Mapru by CB \\
\hline Intercept & $\begin{array}{l}0.5128^{* * *} \\
(0.1073)\end{array}$ & $1.0928^{* * *}$ & $\begin{array}{c}0.0504 \\
0.8886)\end{array}$ & $\begin{array}{c}-0.3148 \\
(0.1651)\end{array}$ \\
\hline \multirow[t]{2}{*}{ OSII Score } & $0.0403^{* * *}$ & $0.0376^{* * *}$ & $\begin{array}{l}(0.8880) \\
0.0277^{* * *}\end{array}$ & $0.0330^{* * *}$ \\
\hline & $(0.0026)$ & $(0.0020)$ & $(0.0022)$ & $(0.0026)$ \\
\hline \multirow[t]{2}{*}{ Subsidiary } & $0.1316^{* *}$ & -0.0015 & -0.0006 & -0.0170 \\
\hline & $(0.0501)$ & $(0.0413)$ & $(0.0433)$ & $(0.0564)$ \\
\hline \multirow[t]{2}{*}{ Target SyRB } & & & $0.2436^{* * *}$ & $0.1478^{* * *}$ \\
\hline & & & $(0.0396)$ & $(0.0223)$ \\
\hline \multirow[t]{2}{*}{ Tier 1 Ratio $(-1)$} & & & $-0.0053^{* *}$ & -0.0024 \\
\hline & & & $(0.0018)$ & $(0.0025)$ \\
\hline \multirow[t]{2}{*}{ Control of Corruption $(-1)$} & & & 0.4690 & $0.2061^{* * *}$ \\
\hline & & & $(0.5818)$ & $(0.0442)$ \\
\hline \multirow[t]{2}{*}{ Operating Income (-1) } & & & $0.0494^{*}$ & $0.1068^{* * *}$ \\
\hline & & & $(0.0195)$ & $(0.0249)$ \\
\hline Mapru by CB & & & & $\begin{array}{l}0.3839^{* * *} \\
(0.0574)\end{array}$ \\
\hline $\mathrm{BE}$ & & $-0.3820^{* * *}$ & 0.1001 & \\
\hline DL & & $(0.0957)$ & $(0.1194)$ & \\
\hline BG & & $-0.5810^{* * *}$ & -0.2033 & \\
\hline & & $(0.1021)$ & $(1.0066)$ & \\
\hline $\mathrm{CY}$ & & $-0.7330^{* * *}$ & 0.0574 & \\
\hline & & $(0.1076)$ & $(0.4389)$ & \\
\hline $\mathrm{CZ}$ & & $-1.4641^{* * *}$ & $-1.1564^{*}$ & \\
\hline & & $(0.1202)$ & $(0.5827)$ & \\
\hline $\mathrm{DE}$ & & $-0.3222^{* * *}$ & -0.2765 & \\
\hline & & $(0.0900)$ & $(0.2025)$ & \\
\hline DK & & $-1.6169^{* * *}$ & $-1.8908^{* * *}$ & \\
\hline & & $(0.1558)$ & $(0.4197)$ & \\
\hline EE & & -0.1703 & -0.0570 & \\
\hline & & $(0.1350)$ & $(0.2064)$ & \\
\hline ES & & $-1.1312^{* * *}$ & -0.2938 & \\
\hline & & $(0.1106)$ & $(0.5919)$ & \\
\hline FI & & $-0.4830^{* *}$ & -0.5327 & \\
\hline & & $(0.1815)$ & $(0.4664)$ & \\
\hline FR & & $-0.6987^{* * *}$ & -0.1626 & \\
\hline & & $(0.1087)$ & $(0.1788)$ & \\
\hline GR & & $-0.9930^{* * *}$ & 0.2927 & \\
\hline & & $(0.1260)$ & $(0.9647)$ & \\
\hline HR & & 0.0438 & 0.3745 & \\
\hline & & $(0.1020)$ & $(0.7770)$ & \\
\hline $\mathrm{HU}$ & & $-0.5863^{* * *}$ & 0.2872 & \\
\hline & & $(0.1161)$ & $(0.8437)$ & \\
\hline IE & & $-0.8196^{* * *}$ & $-0.4639^{* * *}$ & \\
\hline & & $(0.1052)$ & $(0.1305)$ & \\
\hline IS & & -0.1421 & -0.5199 & \\
\hline & & $(0.1576)$ & $(0.2678)$ & \\
\hline IT & & $-1.1676^{* * *}$ & -0.0825 & \\
\hline & & $(0.1285)$ & $(0.8472)$ & \\
\hline LT & & -0.1942 & 0.8147 & \\
\hline & & $(0.1420)$ & $(0.5554)$ & \\
\hline LU & & $-0.5991^{* * *}$ & -0.5525 & \\
\hline & & $(0.1222)$ & $(0.3221)$ & \\
\hline MT & & $-0.3646^{*}$ & 0.5349 & \\
\hline & & $(0.1485)$ & $(0.4555)$ & \\
\hline NL & & -0.2215 & -0.5007 & \\
\hline & & $(0.1550)$ & $(0.2725)$ & \\
\hline PL & & $-0.9330^{* * *}$ & $-0.9790^{*}$ & \\
\hline & & $(0.1024)$ & $(0.4843)$ & \\
\hline PT & & $-0.9772^{* * *}$ & -0.3410 & \\
\hline & & $(0.1208)$ & $(0.3875)$ & \\
\hline RO & & $-0.2040^{*}$ & 0.4795 & \\
\hline & & $(0.0991)$ & $(0.9099)$ & \\
\hline SE & & -0.0142 & -0.3962 & \\
\hline & & $(0.1245)$ & $(0.3942)$ & \\
\hline SI & & $-1.1012^{* * *}$ & -0.3714 & \\
\hline & & $(0.1186)$ & $(0.4328)$ & \\
\hline SK & & $-0.6863^{* * *}$ & -0.0798 & \\
\hline & & $(0.1326)$ & $(0.7705)$ & \\
\hline UK & & $-1.1630^{* * *}$ & $-0.9386^{* * *}$ & \\
\hline & & $(0.0882)$ & $(0.2283)$ & \\
\hline Year 2016 & -0.1345 & -0.0492 & -0.0513 & -0.0184 \\
\hline & $(0.1124)$ & $(0.0832)$ & $(0.0898)$ & $(0.1168)$ \\
\hline Year 2017 & -0.1942 & -0.0360 & -0.0447 & -0.1142 \\
\hline & $(0.1064)$ & $(0.0764)$ & $(0.0839)$ & $(0.1099)$ \\
\hline Year 2018 & -0.1906 & -0.0446 & -0.0174 & -0.0757 \\
\hline & $(0.1062)$ & $(0.0757)$ & $(0.0808)$ & $(0.1101)$ \\
\hline R-squared & 0.35 & 0.77 & 0.79 & 0.47 \\
\hline Adj. R-squared & 0.35 & 0.75 & 0.77 & 0.46 \\
\hline Number of obs. & 473 & 473 & 389 & 389 \\
\hline
\end{tabular}




\section{Appendix E. The OSII Buffer Assignment Process as a Nash Bargaining}

Following Calomiris and Haber (2015) who state that regulation is a complex bargaining between industry and politics, we model the OSII buffer assignment as a bargaining process between the regulatory authority and banks' representatives.

We formalize the discussion in Section 3.2, in particular the weak probabilistic condition. Thus, the interest of the "industry" I comes with higher probability with capture than without. Since every country in the euro area has implemented the OSII framework, regulatory capture might directly occur in the OSII buffer assignment process.

Next, we define the participants of the bargaining process. The first player is the regulatory who is supposed to represent the "interest" of the public. Although it has not been implemented by all countries in our sample, there is an ESRB recommendation on the macroprudential institutional framework (ESRB, 2011b). Most importantly, ESRB (2011b) states that "macro-prudential policy can be pursued by either a single institution or a board composed of several institutions, depending on the national institutional frameworks [..]" and that "the national central banks should have a leading role in macro-prudential oversight because of their expertise and their existing responsibilities in the area of financial stability." As a consequence, in each country a macroprudential authority should be responsible for setting an OSII buffer. In a second step, the same or another authority, namely the designated authority is then responsible for issuing the OSII buffer decisions to the respective banks. Within the national macroprudential institutional framework, there are several possibilities. In some countries the macroprudential authority and the designated authority are the same (BE, CY, CZ, EE, FI, FR, GR, IE, HU, LT, MT, PT, RO, SE, SK and UK). In other countries, these authorities are separated (AT, BG, DE, DK, ES, HR, IT, LV, LU, NL, PL and SI). In two countries, ES and IT no macroprudential authority has been established yet. Within these two general macroprudential institutional frameworks, there are also notable differences. In BE, CY, CZ, EE, GR, HU, IE, LT, MT, PT and SK the central bank is the responsible macroprudential and designated authority. In FI, FR, RO, SE and UK the financial market authority has both responsibilities. In those countries where the responsibilities are separated, different institutions are involved. ${ }^{18}$

The second player is called bank representative. This player could be a bank, more banks, a banking association, representatives from the chamber of commerce or in general representatives from the banking industry.

After describing the two players, we set up a Nash bargaining problem (Nash, 1953). More formally, we arrive at the following definition:

Definition Appendix E.1. (OSII buffer assignment bargaining problem): The OSII buffer assignment bargaining problem is a pair $(S, d)$, where $S \subset R^{2}$ is compact and convex, $d \in S$, and there exists $s \in S$

\footnotetext{
${ }^{18}$ See https://www.esrb.europa.eu/national_policy/shared/pdf/esrb.170825_ list_national_macroprudential_authorities_national_designated_authorities_in_ EUMemberStates. en.pdf for a table with all the details.
} 
such that $s_{i}>d_{i}$ for $i=1,2$. The set of all bargaining problems is denoted $B$. A bargaining solution is $a$ function $f^{\alpha}: B \rightarrow R^{2}$ that assigns to each bargaining problem $(S, d) \in B$ a unique element of $S$.

In Nash (1953), the bargaining problem is not strategically formulated (the complicated details of a bargaining process are left out), but based on axioms (invariance to equivalent utility representations, symmetry, independence of irrelevant alternatives and Pareto efficiency). In our model, we drop the symmetry axiom, as we later define player specific bargaining weights. The bargaining problem also includes the case in which the regulator sets the OSII buffer on its own. The minimal rationale for Definition Appendix E.1 is that the players could have different preferences over the outcome of the OSII buffer assignment process. Following Carpenter (2014) it is also important that there exists some mechanism of undue or disproportionate influence (capture) whereby the industry attempts to induce the regulator to choose I over W. In a typical OSII buffer assignment process, the macroprudential authority has to write a first draft on the OSII buffers and inform all OSIIs about their OSII buffer proposals. Next, the OSIIs have the opportunity to challenge these decisions and might send formal protest letter. In the final step, the designated authority is then responsible for issuing the OSII buffer decisions to the respective OSIIs.

We assume that the OSII buffer assignment bargaining problem is solved for every OSII. Thus, it is straightforward to define the sets $A$ and $S$.

$$
\begin{aligned}
& A=\left\{\left(a_{1}, a_{2}\right) \in R^{2}: a_{1}+a_{2}=2 \text { and } a_{1} \in[0,2], a_{2} \in[0,2]\right\} \\
& S=\left\{\left(s_{1}, s_{2}\right) \in R^{2}:\left(s_{1}, s_{2}\right)=\left(u_{1}\left(a_{1}\right), u_{2}\left(a_{2}\right)\right) \text { for some }\left(a_{1}, a_{2}\right) \in A\right\}
\end{aligned}
$$

We assume that player 1 is the regulator and wants to set a buffer between 0 and 2, depending on certain parameters. Player 2 is a bank representative and has to "pay" for the OSII buffer by holding more capital. Very importantly, $d=\left(d_{1}, d_{2}\right)$ from Definition Appendix E. 1 is called the threat point, which would be the outcome if the players do not reach an agreement. It is not ex-ante clear what these threat points would be but clearly $\left(d_{1}, d_{2}\right) \in A$ (for every OSII there is a buffer). Further restrictions on the threat points could be minimum standards set by an ESRB or EBA recommendation/guideline. In any case, a threat point of $d_{2}=0$ might not be optimal from a macroprudential point of view, especially for banks with a high OSII score.

We also assume that $u_{1}\left(a_{1}\right)$ (the utility function of the regulator) is a differentiable function for each bank. ${ }^{19}$ In particular, based on the OSII score and probably the regulator's buffer assignment model, the regulator calculates an optimal OSII buffer. From Eq. (E.1), we see that $a_{2}=2-a_{1}$, thus $u_{2}\left(2-a_{1}\right)$.

We finally state the Nash bargaining solution without the symmetry assumption:

Definition Appendix E.2. (OSII buffer bargaining solution):

\footnotetext{
${ }^{19}$ Differentiability is not a necessary assumption to find a solution but simplifies the derivation considerably.
} 


$$
\mathbb{N}=\underset{\left(d_{1}, d_{2}\right) \leq\left(u_{1}\left(a_{1}\right), u_{2}\left(2-a_{1}\right)\right) \in S}{\operatorname{argmax}}\left(u_{1}\left(a_{1}\right)-d_{1}\right)^{\alpha}\left(u_{2}\left(2-a_{1}\right)-d_{2}\right)^{1-\alpha}
$$

$\mathbb{N}$ is the Nash product for the bargaining process between the regulator and the banks' representatives. Depending on $\alpha$ given the assumptions of Definition Appendix E.1, Nash (1953) shows that there is a unique solution to the problem:

$$
\begin{aligned}
\frac{\partial \mathbb{N}}{\partial a_{1}}= & \left.\alpha\left(u_{1}\left(a_{1}\right)-d_{1}\right)\right)^{\alpha-1} \frac{\partial u_{1}\left(a_{1}\right)}{\partial a_{1}}\left(u_{2}\left(2-a_{1}\right)-d_{2}\right)^{1-\alpha}+ \\
& \left(u_{1}\left(a_{1}\right)-d_{1}\right)^{\alpha}(1-\alpha)\left(u_{2}\left(2-a_{1}\right)-d_{2}\right)^{-\alpha} \frac{\partial u_{2}\left(2-a_{1}\right)}{\partial a_{1}}=0 \\
= & \alpha \frac{\partial u_{1}\left(a_{1}\right)}{\partial a_{1}}\left(u_{2}\left(2-a_{1}\right)-d_{2}\right)+\left(u_{1}\left(a_{1}\right)-d_{1}\right)(1-\alpha) \frac{\partial u_{2}\left(2-a_{1}\right)}{\partial a_{1}}=0
\end{aligned}
$$

If we set $d_{1}=d_{2}=0, \alpha=1 / 2$ and make $u_{1}, u_{2}$ linear in $a_{1}$, then we arrive at the well-known "divide a penny" Nash bargaining solution of $a_{1}^{*}=a_{2}^{*}=1$. However, the OSII buffer assignment is not such a simple division of a penny.

Aside from these theoretical considerations (which are numerous in the literature), there are surprisingly only a few papers that ask the important question: What variables influence $d_{1}, d_{2}, s_{1}, s_{2}, \alpha$ and hence the bargaining outcome (in our case the $\left.u_{1}\left(a_{1}^{*}\right)=O S I I B^{*}\right)$ ? One notable exception is the Nobel Prize winning Diamond-Mortensen-Pissarides theory of equilibrium unemployment (Pissarides, 2000). In their theory, the wage in a matched vacancy-job pair is divided by a Nash bargaining between the employee and the employer.

Thus, we start by defining the utility function of the regulator. We make the following assumptions: (1) $u_{1}\left(a_{1}\right)$ is differentiable on the closed interval [0,2]. (2) There is an optimal OSII buffer $\left(O S I I B^{*}\right)$ from the regulator's point of view, which positively depends on the OSII score. Next, we make assumption about the threat point $d_{1}$. Under the current regulation, where in most countries the higher of the SyRB and OSII buffer is binding, we consider the SyRB as a potential threat point. The bargaining weight of the regulator is most probably determined by the national macroprudential institutional framework. We proxy this bargaining weight by a country dummy and by the variable control of corruption $(-1)$ (see Kaufmann et al. (2011) and Section 3.2).

The utility function of the banks' representatives is also assumed to be differentiable in $a_{1}$ on the closed interval [0,2]. A lower OSII buffer is assumed to increase the utility, even if a potential buffer is not binding. Banks' representatives still prefer a higher "management buffer" (difference between the current capital ratio and the regulatory minimum). Moreover, it is easier to accept an OSII buffer, if it is not binding. The threat point $d_{2}$ of the banks' representatives also depends on the SyRB. We assume that the Tier 1 capital ratio and the operating income ratio are parts of the banks' representative threat point $d_{2}$. At this point it should also be mentioned that the capital ratio of a bank is, next to the loss given default (which is based on a score similar to the OSII score), the second part of the expected impact approach of FED (2015).

With these assumptions, we further simplify Eq. (E.3) 


$$
\begin{aligned}
0= & \alpha\left(2-\text { OS IIB }^{*}-\left(\beta_{1} T 1 C R+\beta_{2} S y R B+\beta_{3} \text { OIR }\right)\right)-(1-\alpha)\left(\text { OS IIB }^{*}-\right. \\
& \left.\left(\gamma_{1} \text { OS IIS }+\gamma_{2} S y R B\right)\right), \\
\text { OS IIB }^{*}= & 2 \alpha+\gamma_{1}(1-\alpha) * \text { OS IIS }-\alpha * \beta_{1} T 1 C R-\alpha * \beta_{3} \text { OIR }+\left[(1-\alpha) \gamma_{2}-\alpha \beta_{2}\right] S y R B .
\end{aligned}
$$

From the theoretical solution in Eq. (E.4), we see that the bargaining power of the regulator partially defines the coefficient of all variables. As a consequence, we have two options. First, we could estimate the average structural parameters of OSIIS, T1CR and SyRB and country dummies as in all the other tables of the paper. Second, we could estimate a country specific model for each country. The advantages of the first option are straightforward. We can compare the results to the other tables in particular to Table 6 and we can use more observations to estimate the parameters. The advantages of the second approach are country specific structural parameters.

For estimating the average structural parameters of OSIIS, T1CR and SyRB and country dummies, we specify the following reduced from equation:

$$
O S I I B_{i}^{*}=\phi_{0}^{C}+\phi_{1} O S I I S_{i}+\phi_{2} T 1 C R_{i}+\phi_{3} O I R_{i}+\phi_{4} S y R B_{i}+\epsilon_{i}
$$

In Eq. (E.4), $i$ refers to observation $i=1, \ldots, N$ and $\phi_{0}^{C}$ to the country specific intercept. $\phi_{1}, \phi_{2}, \phi_{3}$ and $\phi_{4}$ are the respective reduced from parameters for the explanatory variables. It is possible to derive many structural parameters from Eq. (E.4) from the reduced form coefficients:

$$
\begin{aligned}
& \alpha=\frac{\phi_{0}^{C}}{2} \\
& \gamma_{1}=\frac{\phi_{1}}{1-\alpha} \\
& \beta_{1}=\frac{\delta_{T I C R}}{\alpha} \\
& \beta_{3}=\frac{\delta_{O I R}}{\alpha} \\
& \gamma_{2}=\frac{\delta_{S Y R B}+\alpha_{i} \beta_{2}}{1-\alpha_{i}}
\end{aligned}
$$

Since the SyRB is part of both utility functions, we cannot exactly extract $\gamma_{1}$ and $\beta_{2}$, but safely assume that $\gamma_{1}>0$ and $\beta_{2}<0$. Overall, we therefore always expect a positive impact of the SyRB on the $O S I I B^{*}$ independent of the bargaining weights. We further do not estimate an intercept and restrict the country dummies to lie between 0 and 2, as suggested by Eq. (Appendix E.2). ${ }^{20}$

\footnotetext{
${ }^{20}$ We use the code of Vanbrabant (2020) to implement these parameter restrictions. The theory on linear models with inequality restrictions is derived from Silvapulle and Sen (2005).
} 
Table E.13: OLS Estimation: Restricted Models

\begin{tabular}{|c|c|c|}
\hline & Score and Country Dummies & Regulatory Capture \\
\hline OSII Score & $0.0377^{* * *}$ & $0.0323^{* * *}$ \\
\hline Target SyRB & & $\begin{array}{l}0.1810^{* * *} \\
(0.0285)\end{array}$ \\
\hline \multirow[t]{2}{*}{ Tier 1 Ratio $(-1)$} & & $-0.0072^{* * * *}$ \\
\hline & & $(0.0017)$ \\
\hline \multirow[t]{2}{*}{ Operating Income (-1) } & & -0.0112 \\
\hline & & $(0.0171)$ \\
\hline \multirow[t]{2}{*}{ AT } & $1.0483^{* * *}$ & $0.9766^{* * *}$ \\
\hline & $(0.0748)$ & $(0.0867)$ \\
\hline \multirow[t]{2}{*}{$\mathrm{BE}$} & $0.6768^{* * *}$ & $0.9707^{* * *}$ \\
\hline & $(0.0611)$ & $(0.0905)$ \\
\hline \multirow[t]{2}{*}{ BG } & $0.4831^{* * *}$ & $0.1950^{*}$ \\
\hline & $(0.0611)$ & $(0.0986)$ \\
\hline \multirow[t]{2}{*}{$\mathrm{CY}$} & $0.3167^{* * *}$ & $0.6209^{* * *}$ \\
\hline & $(0.0790)$ & $(0.1050)$ \\
\hline \multirow[t]{2}{*}{$\mathrm{DE}$} & $0.7265^{* * *}$ & $0.7510^{* * *}$ \\
\hline & $(0.0515)$ & $(0.0610)$ \\
\hline \multirow[t]{2}{*}{ EE } & $0.8770^{* * *}$ & $0.8228^{* * *}$ \\
\hline & $(0.1144)$ & $(0.1247)$ \\
\hline \multirow[t]{2}{*}{ ES } & 0.0000 & 0.1030 \\
\hline & $(0.0000)$ & $(0.1022)$ \\
\hline \multirow[t]{2}{*}{ FI } & $0.5721^{* * * *}$ & $0.6940^{* *}$ \\
\hline & $(0.1640)$ & $(0.2214)$ \\
\hline \multirow[t]{2}{*}{ FR } & $0.3497^{* * *}$ & $0.5533^{* * *}$ \\
\hline & $(0.0830)$ & $(0.1034)$ \\
\hline \multirow[t]{2}{*}{ GR } & 0.0709 & $0.3536^{* *}$ \\
\hline & $(0.1031)$ & $(0.1287)$ \\
\hline \multirow[t]{2}{*}{$\mathrm{HR}$} & $1.0913^{* * *}$ & $0.8907^{* * *}$ \\
\hline & $(0.0679)$ & $(0.0981)$ \\
\hline $\mathrm{HU}$ & $0.4640^{* * *}$ & $0.6361^{* * *}$ \\
\hline & $(0.0830)$ & $(0.1132)$ \\
\hline IE & $0.2283^{* *}$ & $0.4053^{* * *}$ \\
\hline & $(0.0765)$ & $(0.1027)$ \\
\hline IS & $0.9080^{* * *}$ & $0.7530^{* * *}$ \\
\hline & $(0.1419)$ & $(0.1531)$ \\
\hline IT & 0.0000 & 0.0922 \\
\hline & $(0.0000)$ & $(0.1188)$ \\
\hline LT & $0.8554^{* * *}$ & $1.1680^{* * *}$ \\
\hline & $(0.1212)$ & $(0.1759)$ \\
\hline LU & $0.4507^{* * *}$ & $0.5904^{* * *}$ \\
\hline & $(0.0944)$ & $(0.1193)$ \\
\hline MT & $0.7011^{* * *}$ & $1.0612^{* * *}$ \\
\hline & $(0.1247)$ & $(0.1492)$ \\
\hline NL & $0.8229^{* * *}$ & $0.5693^{* * *}$ \\
\hline & $(0.1361)$ & $(0.1666)$ \\
\hline PL & 0.1183 & 0.0000 \\
\hline & $(0.0689)$ & $(0.0000)$ \\
\hline PT & 0.0736 & $0.2115^{*}$ \\
\hline & $(0.0968)$ & $(0.1010)$ \\
\hline RO & $0.8435^{* * *}$ & $0.8288^{* * *}$ \\
\hline & $(0.0632)$ & $(0.0915)$ \\
\hline SE & $1.0496^{* * *}$ & $0.8709^{* * *}$ \\
\hline & $(0.1006)$ & $(0.1156)$ \\
\hline SI & 0.0000 & 0.1963 \\
\hline & $(0.0000)$ & (0.1099) \\
\hline SK & $0.3635^{* * *}$ & $0.3217^{*}$ \\
\hline & $(0.1059)$ & $(0.1250)$ \\
\hline UK & 0.0000 & 0.0591 \\
\hline & $(0.0000)$ & $(0.0779)$ \\
\hline Adj. R-squared & 0.92 & 0.93 \\
\hline Number of obs. & 453 & 371 \\
\hline${ }^{* * *} p<0.001,{ }^{* *} p<0$ & ${ }^{*} p<0.05$ & \\
\hline Source: Authors' calcu & $\begin{array}{l}\text { ions. } \\
\text { ltss of estimating Eg. (E.5) und }\end{array}$ & \\
\hline $\begin{array}{l}\text { This table shows the } r \\
\text { country dummies. The }\end{array}$ & $\begin{array}{l}\text { alts of estimating Eq. (E.5) und } \\
\text { pendent variable is the OSII bu }\end{array}$ & $\begin{array}{l}\text { the restrictions on the } \\
\text { r. }\end{array}$ \\
\hline $\begin{array}{l}\text { In the first column, we } \\
\text { on the OSII buffer. }\end{array}$ & st the hypothesis that the OSII s & has a positive impact \\
\hline The second column, w & $d$ the bank specific explanator & ariables. \\
\hline
\end{tabular}

The results of the first empirical implementation can be found in Table E.13. As defined in Eq. (E.6), the bargaining powers of the regulators can be calculated by dividing the country dummies by 2 . The results confirm our previous findings, a high degree of country heterogeneity in the OSII buffer assignment. 
Only in a few cases the imposed restrictions on the country dummies are binding. In all these cases, the lower bound of the interval $[0,2]$ is binding. In general, introducing the inequality constraints on the parameters do not change the results significantly, which can be seen by comparing Table E.13 to Table C.11. It is remarkable how few regulators have an $\alpha$ (bargaining power) close to or greater than 0.5. As a consequence, the OSII buffers of banks in many countries is quite low compared to similar banks in other countries. In some countries the estimated bargaining powers of the regulators are even close to 0 .

Second, for the country specific models, in order to maximize the number of observations per country, we only estimate the model "Score and Country Dummies". Now it is possible to derive our two structural parameters, $\alpha$ and $\gamma_{1}$. 
Table E.14: OLS Estimation: Country-by-country estimation

\begin{tabular}{l|rrrr|rr}
\hline & Intercept & Score & Number of Obs. & R-Squared & $\alpha$ & $\gamma_{1}$ \\
\hline AT & 0.80 & 0.06 & 20 & 0.84 & 0.40 & 0.10 \\
BE & 0.66 & 0.04 & 32 & 0.83 & 0.33 & 0.06 \\
BG & 0.53 & 0.03 & 30 & 0.62 & 0.27 & 0.04 \\
CY & 0.0 & 0.07 & 18 & 0.97 & 0.00 & 0.07 \\
CZ & 0.00 & 0.00 & 14 & & 0.00 & 0.00 \\
DE & 0.64 & 0.06 & 41 & 0.76 & 0.32 & 0.08 \\
DK & 0.00 & 0.00 & 6 & & 0.00 & 0.00 \\
EE & 0.23 & 0.07 & 9 & 0.62 & 0.12 & 0.08 \\
ES & 0.16 & 0.02 & 16 & 0.93 & 0.08 & 0.02 \\
FI & 0.07 & 0.08 & 4 & 0.95 & 0.04 & 0.08 \\
FR & 0.13 & 0.05 & 17 & 0.95 & 0.07 & 0.06 \\
GR & 1.00 & 0.00 & 12 & 0.51 & 0.50 & 0.00 \\
HR & 0.96 & 0.05 & 25 & 0.30 & 0.48 & 0.09 \\
HU & 0.24 & 0.06 & 16 & 0.91 & 0.12 & 0.07 \\
IE & 0.00 & 0.06 & 19 & 0.53 & 0.00 & 0.06 \\
IS & 2.00 & 0.00 & 6 & 0.41 & 1.00 & -0.03 \\
IT & 0.16 & 0.02 & 10 & 0.99 & 0.08 & 0.03 \\
LT & 0.90 & 0.04 & 8 & 0.53 & 0.45 & 0.06 \\
LU & 0.06 & 0.12 & 12 & 0.90 & 0.03 & 0.13 \\
MT & 0.21 & 0.08 & 7 & 0.74 & 0.10 & 0.09 \\
NL & 0.90 & 0.03 & 6 & 0.57 & 0.45 & 0.06 \\
PL & 0.00 & 0.06 & 23 & 0.93 & 0.00 & 0.06 \\
PT & 0.13 & 0.03 & 12 & 0.94 & 0.06 & 0.04 \\
RO & 1.07 & 0.01 & 28 & 0.02 & 0.53 & 0.02 \\
SE & 1.40 & 0.02 & 12 & 0.19 & 0.70 & 0.07 \\
SI & 0.01 & 0.03 & 13 & 0.95 & 0.01 & 0.03 \\
SK & 0.87 & 0.00 & 10 & 0.00 & 0.43 & 0.00 \\
UK & 0.09 & 0.00 & 47 & 0.01 & 0.05 & 0.00 \\
\hline & & & & & &
\end{tabular}

${ }^{* * *} p<0.001,{ }^{* *} p<0.01,{ }^{*} p<0.05$.

Source: Authors' calculations.

In each row, the OLS bargaining solution is estimated by only including the respective country data.

In the first column the intercept is reported. According to Eq. (E.4) it is $2 \times \alpha$, which is the bargaining power of the regulator, which is reported in the $\alpha$-column.

The coefficient of the OSII score is reported in column "Score". Again, according to Eq. (E.4), we calculate the structural parameter $\gamma_{1}$ by dividing the "Score" coefficient by $1-\alpha$.

In Table E.14, we present our results. Since the number of observations per country varies from 6 to 47 , hence some country results are more unreliable than others. The estimated $\alpha$ 's confirm our previous findings. The large country heterogeneity can be attributed to different bargaining powers of the regulatory. It is also interesting to see how differently the OSII score is taken into account across countries. In some countries the OSII score is an important determinant of the OSII buffers, whereas in 
others $\gamma_{1}$ is close to zero or even negative. 


\section{Index of Working Papers:}

\begin{tabular}{|c|c|c|c|}
\hline $\begin{array}{l}\text { June 15, } \\
2015\end{array}$ & Anil Ari & 202 & Sovereign Risk and Bank Risk-Taking \\
\hline $\begin{array}{l}\text { June 15, } \\
2015\end{array}$ & Matteo Crosignani & 203 & $\begin{array}{l}\text { Why Are Banks Not Recapitalized During } \\
\text { Crises? }\end{array}$ \\
\hline $\begin{array}{l}\text { February 19, } \\
2016\end{array}$ & Burkhard Raunig & 204 & Background Indicators \\
\hline $\begin{array}{l}\text { February 22, } \\
2016\end{array}$ & $\begin{array}{l}\text { Jesús Crespo } \\
\text { Cuaresma, } \\
\text { Gernot Doppelhofer, } \\
\text { Martin Feldkircher, } \\
\text { Florian Huber }\end{array}$ & 205 & US Monetary Policy in a Globalized World \\
\hline $\begin{array}{l}\text { March 4, } \\
2016\end{array}$ & $\begin{array}{l}\text { Helmut Elsinger, } \\
\text { Philipp Schmidt- } \\
\text { Dengler, } \\
\text { Christine Zulehner }\end{array}$ & 206 & Competition in Treasury Auctions \\
\hline $\begin{array}{l}\text { May 14, } \\
2016\end{array}$ & $\begin{array}{l}\text { Apostolos } \\
\text { Thomadakis }\end{array}$ & 207 & $\begin{array}{l}\text { Determinants of Credit Constrained Firms: } \\
\text { Evidence from Central and Eastern Europe } \\
\text { Region }\end{array}$ \\
\hline $\begin{array}{l}\text { July } 1 \\
2016\end{array}$ & $\begin{array}{l}\text { Martin Feldkircher, } \\
\text { Florian Huber }\end{array}$ & 208 & $\begin{array}{l}\text { Unconventional US Monetary Policy: New } \\
\text { Tools Same Channels? }\end{array}$ \\
\hline $\begin{array}{l}\text { November 24, } \\
2016\end{array}$ & François de Soyres & 209 & $\begin{array}{l}\text { Value Added and Productivity Linkages } \\
\text { Across Countries }\end{array}$ \\
\hline $\begin{array}{l}\text { November 25, } \\
2016\end{array}$ & Maria Coelho & 210 & $\begin{array}{l}\text { Fiscal Stimulus in a Monetary Union: } \\
\text { Evidence from Eurozone Regions }\end{array}$ \\
\hline $\begin{array}{l}\text { January 9, } \\
2017\end{array}$ & $\begin{array}{l}\text { Markus Knell, } \\
\text { Helmut Stix }\end{array}$ & 211 & Inequality, Perception Biases and Trust \\
\hline $\begin{array}{l}\text { January } 31, \\
2017\end{array}$ & $\begin{array}{l}\text { Steve Ambler, } \\
\text { Fabio Rumler }\end{array}$ & 212 & $\begin{array}{l}\text { The Effectiveness of Unconventional } \\
\text { Monetary Policy Announcements in the Euro } \\
\text { Area: An Event and Econometric Study }\end{array}$ \\
\hline $\begin{array}{l}\text { May 29, } \\
2017\end{array}$ & Filippo De Marco & 213 & $\begin{array}{l}\text { Bank Lending and the European Sovereign } \\
\text { Debt Crisis }\end{array}$ \\
\hline $\begin{array}{l}\text { June } 1 \\
2017\end{array}$ & Jean-Marie Meier & 214 & $\begin{array}{l}\text { Regulatory Integration of International } \\
\text { Capital Markets }\end{array}$ \\
\hline
\end{tabular}




\begin{tabular}{|c|c|c|c|}
\hline $\begin{array}{l}\text { October 13, } \\
2017\end{array}$ & Markus Knell & 215 & Actuarial Deductions for Early Retirement \\
\hline $\begin{array}{l}\text { October 16, } \\
2017\end{array}$ & $\begin{array}{l}\text { Markus Knell, } \\
\text { Helmut Stix }\end{array}$ & 216 & Perceptions of Inequality \\
\hline $\begin{array}{l}\text { November 17, } \\
2017\end{array}$ & $\begin{array}{l}\text { Engelbert J. Dockner, } \\
\text { Manuel Mayer, } \\
\text { Josef Zechner }\end{array}$ & 217 & Sovereign Bond Risk Premiums \\
\hline $\begin{array}{l}\text { December 1, } \\
2017\end{array}$ & $\begin{array}{l}\text { Stefan Niemann, } \\
\text { Paul Pichler }\end{array}$ & 218 & $\begin{array}{l}\text { Optimal fiscal policy and sovereign debt } \\
\text { crises }\end{array}$ \\
\hline $\begin{array}{l}\text { January } 17, \\
2018\end{array}$ & Burkhard Raunig & 219 & $\begin{array}{l}\text { Economic Policy Uncertainty and the } \\
\text { Volatility of Sovereign CDS Spreads }\end{array}$ \\
\hline $\begin{array}{l}\text { February 21, } \\
2018\end{array}$ & $\begin{array}{l}\text { Andrej Cupak, } \\
\text { Pirmin Fessler, } \\
\text { Maria Silgoner, } \\
\text { Elisabeth Ulbrich }\end{array}$ & 220 & $\begin{array}{l}\text { Exploring differences in financial literacy } \\
\text { across countries: the role of individual } \\
\text { characteristics and institutions }\end{array}$ \\
\hline $\begin{array}{l}\text { May 15, } \\
2018\end{array}$ & $\begin{array}{l}\text { Peter Lindner, } \\
\text { Axel Loeffler, } \\
\text { Esther Segalla, } \\
\text { Guzel Valitova, } \\
\text { Ursula Vogel }\end{array}$ & 221 & $\begin{array}{l}\text { International monetary policy spillovers } \\
\text { through the bank funding channel }\end{array}$ \\
\hline $\begin{array}{l}\text { May 23, } \\
2018\end{array}$ & $\begin{array}{l}\text { Christian A. Belabed, } \\
\text { Mariya Hake }\end{array}$ & 222 & $\begin{array}{l}\text { Income inequality and trust in national } \\
\text { governments in Central, Eastern and } \\
\text { Southeastern Europe }\end{array}$ \\
\hline $\begin{array}{l}\text { October 16, } \\
2018\end{array}$ & $\begin{array}{l}\text { Pirmin Fessler, } \\
\text { Martin Schürz }\end{array}$ & 223 & $\begin{array}{l}\text { The functions of wealth: renters, owners and } \\
\text { capitalists across Europe and the United } \\
\text { States }\end{array}$ \\
\hline $\begin{array}{l}\text { October 24, } \\
2018\end{array}$ & $\begin{array}{l}\text { Philipp Poyntner, } \\
\text { Thomas Reininger }\end{array}$ & 224 & $\begin{array}{l}\text { Bail-in and Legacy Assets: Harmonized } \\
\text { rules for targeted partial compensation to } \\
\text { strengthen the bail-in regime }\end{array}$ \\
\hline $\begin{array}{l}\text { Dezember 14, } \\
2018\end{array}$ & $\begin{array}{l}\text { Thomas Breuer, } \\
\text { Martin Summer }\end{array}$ & 225 & Systematic Systemic Stress Tests \\
\hline May 20, 2019 & Helmut Stix & 226 & $\begin{array}{l}\text { Ownership and purchase intention of crypto- } \\
\text { assets - survey results }\end{array}$ \\
\hline $\begin{array}{l}\text { October 17, } \\
2019\end{array}$ & $\begin{array}{l}\text { Markus Knell, } \\
\text { Helmut Stix }\end{array}$ & 227 & $\begin{array}{l}\text { How Peer Groups Influence Economic } \\
\text { Perceptions }\end{array}$ \\
\hline
\end{tabular}




\begin{tabular}{|c|c|c|c|}
\hline $\begin{array}{l}\text { February 26, } \\
2020\end{array}$ & Helmut Elsinger & 228 & Serial Correlation in Contingency Tables \\
\hline $\begin{array}{l}\text { March 2, } \\
2020\end{array}$ & $\begin{array}{l}\text { Mariarosaria } \\
\text { Comunale, } \\
\text { Markus Eller, } \\
\text { Mathias Lahnsteiner }\end{array}$ & 229 & $\begin{array}{l}\text { Assessing Credit Gaps in CESEE Based on } \\
\text { Levels Justified by Fundamentals -A } \\
\text { Comparison Across Different Estimation } \\
\text { Approaches }\end{array}$ \\
\hline $\begin{array}{l}\text { April 30, } \\
2020\end{array}$ & $\begin{array}{l}\text { Martin Brown, } \\
\text { Nicole Hentschel, } \\
\text { Hannes Mettler, } \\
\text { Helmut Stix }\end{array}$ & 230 & $\begin{array}{l}\text { Financial Innovation, Payment Choice and } \\
\text { Cash Demand - Causal Evidence from the } \\
\text { Staggered Introduction of Contactless Debit } \\
\text { Cards }\end{array}$ \\
\hline $\begin{array}{l}\text { July } 30 \\
2020\end{array}$ & $\begin{array}{l}\text { Katharina Drescher, } \\
\text { Pirmin Fessler, } \\
\text { Peter Lindner }\end{array}$ & 231 & $\begin{array}{l}\text { Helicopter Money in Europe: New Evidence } \\
\text { on the Marginal Propensity to Consume } \\
\text { across European Households }\end{array}$ \\
\hline $\begin{array}{l}\text { November 20, } \\
2020\end{array}$ & Michael Sigmund & 232 & $\begin{array}{l}\text { The Capital Buffer Calibration for } \\
\text { Other Systemically Important Institutions - } \\
\text { Is the Country Heterogeneity in the EU } \\
\text { caused by Regulatory Capture? }\end{array}$ \\
\hline
\end{tabular}

